\title{
Science, Technology, and Administrative Government: Institutional Designs for Environmental Decisionmaking
}

\author{
Joel Yellin $†$
}

When Felix Frankfurter evaluated the prospects for administrative government in these pages in the 1938 predecessor to this Symposium, he observed that "[s]cience and technology cannot reshape society while law maintains its Blackstonian essences."1 For Frankfurter, the passing of the Blackstonian era was marked by a change in institutional roles: Government's growing concern with the quality of people's lives led to a stream of public law that would largely flow, not from the legislature and the courts, but from a burgeoning administrative structure. ${ }^{2}$

As Frankfurter foresaw, an administrative state with extensive regulatory powers emerged from the New Deal. But with respect to science and technology, the administrative state has responsibilities far broader than Roosevelt-era reformers envisioned. In maintaining air and water quality, and assuring the safety of drugs, nuclear reactors, and workplaces, government no longer plays only a regulatory role. Administrators, legislators, and judges are asked to analyze and shape the scientific and technological future.

This expansion of government's responsibilities has important implications for environmental decisionmaking. Part $I$ of this Article argues that the use of sophisticated mathematical and biological models distinguishes modern administrative experts from their Roosevelt-era predecessors. These models distance a modern agency's reasoning from ordinary experience and insulate regulatory decisions from generalist review. Appellate courts have responded by broadening the scope of judicial review. However, this response threatens the viability of the traditional model of administrative law, which is based on the assumption that courts will defer to agencies in matters of substance. The simplest reply to this threat is to

$\dagger$ Senior Research Scientist, Massachusetts Institute of Technology. This work was supported in part by the Center for Energy Policy Research of the M.I.T. Energy Laboratory.

1. Frankfurter, Foreword, 47 YALE L.J. 515, 515 (1938). I respond here to Frankfurter's vision of a creative legal system evolving in response to technological change. His emphasis was very different from mine. Frankfurter's discussion centers on the nature, role, and recognition of administrative law, see id. at 517-natural concerns in an era in which conservative critiques of the administrative state retained a powerful hold on legal thought. See id. at 517-18.

2. Id. at 518-18a. 
separate technology from law by entrusting complex technical issues to special institutions, leaving the relationship between courts and agencies unchanged. Part II argues that this strategy-however promising in theory-cannot succeed, given the intertwined roles of technical judgments and ethical choices in formulating the standards of proof central to environmental decisions. Part III examines the thesis that the traditional model of administrative law can be preserved provided the courts give special deference to regulatory fact-finding on the frontiers of science and technology. Using as examples the most recent stages of the Vermont Yankee litigation, it argues that this super-deferential approach neither contributes to the balance among institutions necessary for a vital administrative process, nor encourages the reasoned decisionmaking essential to the legitimacy of the modern administrative state. Part IV explores possibilities for institutional redesign and concludes with three proposals designed to incorporate science and technology more deeply into decisionmaking.

I.

The designers of the modern administrative state justified the expansion of regulatory power as a necessary response to the growing complexity of society. ${ }^{3}$ New Deal reformers were concerned primarily with economic complexity, not with science and technology. Yet their approach to economic regulation set a pattern for the technological future. In particular, reformers sought to promote social and economic welfare through "expert" decisionmaking. They argued that if legislative policies are to be carried out fully, administrative experts must be free of constraints imposed by judges and other non-expert political appointees. ${ }^{\mathrm{B}}$

Following unsuccessful efforts to persuade the courts that the administrative state was constitutionally illegitimate, conservatives, believing that agency experts were partisan advocates whose decisions escaped independent checks, demanded more active judicial oversight of regulatory deci-

3. See, e.g., J. LANDIS, THE ADMINISTRaTIVE PROcESS 68, 126 (1938); Cooper, Administrative Justice and the Role of Discretion, 47 YALE L.J. 577, 580-81, 597, 599 (1938); Frankfurter, supra note 1, at 518a-18b (quoting Hughes, Some Aspects of Development of American Law, 39 REP. N.Y. STATE BAR ASS'N 266, 269 (1916)); Fuchs, Concepts and Policies in Anglo-American Administrative Law Theory, 47 YALE L.J. 538, 546 (1938); Redmond, The Securities Exchange Act of 1934: An Experiment in Administrative Law, 47 YALE L.J. 622, 622 (1938).

4. See, e.g., Cooper, supra note 3, at 595; cf. Dickinson, Judicial Control of Official Discretion, 22 AM. POL. SCI. REV. 275, 277 (1928) (administration by technical experts "bridge[s] the gap between popular government and scientific government"). Justice Brandeis is often credited with the earliest definitive statement of the advantages of expertise. See Great N. Ry. v. Merchants Elevator Co., 259 U.S. 285, 292 (1922) (Brandeis, J.).

5. See, e.g., Cooper, supra note 3, at 599-600. 
sions. ${ }^{6}$ New Deal proponents responded by pointing to the traditional functional distinctions between fact and law. They argued that judicial review should, as far as practicable, be limited to legal matters, and that the respective areas of competence of judges, legislators, and administrators should define the boundaries between law and fact. ${ }^{7}$ The result was a political compromise: ${ }^{8}$ the crystallization in statutory form of the traditional model of administrative law $^{9}$ in which the legislature maps the boundaries of regulatory authority; agencies act, with a Marshallian filling-in of details; ${ }^{\mathbf{1 0}}$ and reviewing courts keep administrative power within statutory limits. ${ }^{11}$ Thus was laid the groundwork for the modern approach to environmental decisions in which agencies oversee industrial activities and assign the associated physical, biological, and statistical problems to experts, implicitly or explicitly assuming that these problems are separable from the larger legal, political, and ethical considerations traditionally reserved for policymakers.

The assumptions underlying the New Deal compromise no longer hold. The earlier controversies over ratesetting and valuation posed subtle and difficult questions, as examination of the judicial record-even at the rarified appellate level一attests. ${ }^{12}$ But the modern era adds something more: the incorporation into political life of sophisticated quantitative methods for predicting the outcomes of social decisions. The expertise of the New Deal thus differs fundamentally from the expertise now associated with

6. See, e.g., Report of the Special Committee on Administrative Law, 24 A.B.A.J. 331, 344-45 (1939) (decrying partisan experts); PRESIDENT's COMM. ON ADMINISTRATIVE MANAGEMENT, REPORT WITH SPECLAL STUDIES 39-40 (1937) (Brownlow report) (characterizing agencies as "miniature administrative governments"). See generally Verkuil, The Emerging Concept of Administrative Procedure, 78 COLUM. L. REV. 258, 268-78 (1978) (describing conservatives' shift from substantive opposition to New Deal legislation to demands for thoroughgoing judicial control of administrative actions).

7. J. LANDIS, supra note 3, at 152 .

8. Justice Jackson, a Roosevelt appointee, recognized the political compromise, see Wong Yang Sung v. McGrath, 339 U.S. 33, 40 (1950) (Jackson, J.), and its far-reaching implications for the nature and power of the administrative state, see FTC v. Ruberoid Co., 343 U.S. 470, 487-89 (1952) (Jackson, J., dissenting).

9. See Stewart, The Reformation of American Administrative Law, 88 HARV. L. REV. 1667, 1671-76 (1975).

10. See Wayman v. Southard, 23 U.S. (10 Wheat.) 1, 15-16, 42 (1825) (Marshall, C.J.); see also Panama Ref. Co. v. Ryan, 293 U.S. 388, 421 (1935) (attempting to limit delegation of powers, but noting national "legislation must often be adapted to complex conditions involving a host of details with which [Congress] cannot deal directly"); Cooper, supra note 3, at 581-83 (Congress not competent to define fully complex regulatory standards for labor-industry relations and securities markets); id. at 587 (duty of administering general provisions of regulatory statutes inevitably was entrusted to agencies "authorized to fill up the details of the statutes" and ascertain facts toward which statutes are directed).

11. See, e.g., Monaghan, Marbury and the Administrative State, 83 COLUM. L. REV. 1, 6, 27, 33 (1983); cf. J. LANDIS, supra note 3, at 25-26 (demand for expertise "naturally leads to . . . authorities limited in their sphere of action to the new tasks that government may conclude to undertake").

12. See, e.g., Missouri ex rel. Southwestern Bell Tel. Co. v. Public Serv. Comm'n, 262 U.S. 276 (1923); 1 A. KAHN, THE ECONOMICS OF REgULATION 3-57 (1970); Lilienthal, Regulation of Public Utilities During the Depression, 46 HARV. L. REV. 745, 745-55, 763-68 (1933). 


\section{Environmental Decisionmaking}

environmental decisions. The New Deal did not require agency analysts to solve the partial differential equations governing the diffusion of pollutants in air and water, to manipulate epidemiological data, or to investigate the mutagenic effects of industrial chemicals. It called instead for learning through practical experience about the operations of industry and government. ${ }^{13}$ As James Landis put it, the crying need was for "men bred to the facts."14

Moreover, the statutes defining a modern agency's mission no longer map the boundaries of real institutional authority. ${ }^{15}$ Modern environmental statutes are diffuse. They require regulators to predict and control the full spectrum of unwanted side effects of industrial activities. ${ }^{16}$ These statutes authorize agency participation in large-scale research and project development; ${ }^{17}$ they require regulators to anticipate the environmental consequences of major federal decisions. ${ }^{18}$ Roosevelt-era legislation had no such scope. Quintessential New Deal agencies such as the Securities and Exchange Commission (SEC) and National Labor Relations Board (NLRB) primarily had licensing and enforcement powers. The New Deal

13. See, e.g., L. JAFFe, JUDIClal CONTROL OF ADMINISTRATIVE ACTION 579 (1965); J. LANDIS, supra note 3 , at $23-24,155$.

14. J. LaNDIS, supra note 3, at 155.

15. Nor has the New Deal's faith in technical expertise been vindicated. The passage in 1946 of the Administrative Procedure Act (APA), Pub. L. No. 76-404, 60 Stat. 237 (1946) (current version codified at 5 U.S.C. $\S \S 551-559,701-706$ (1982)), formally ratified the compromise between New Deal reformers and conservative opponents of administrative government. In the same year, Congress established the Atomic Energy Commission (AEC), the first federal agency authorized to engage in research, development, and industrial production. There could have been no more stringent test of the New Deal model than the one it underwent as the AEC developed its military and commercial programs. The Commission combined scientific, engineering, and managerial skills of the highest order. Reactor development was pushed ahead and siting and safety decisions were made, often with minimal impetus and direction from policy levels. See 1 R. HEWLETT \& O. ANDERSON, A HISTORY OF THE UNITED STATES ATOMIC ENERGY COMMISSION 227-54 (1969). Yet the Commission did not achieve the success the New Deal had promised. Its arcane subject, the national security implications of its actions, and the domestic political tensions of the postwar era led to a decisionmaking process dominated by highly committed engineers and scientists and closed to effective review by outsiders. When the results of that process were evaluated, in the era of commercial nuclear power, it was found that the agency had failed to establish quality control in manufacturing, to train personnel adequately, to promote "learning by doing," and generally to establish a safe and efficient nuclear power system. See, e.g., REPORT OF THE PRESIDENT's COMM'N ON THE ACCIDENT AT THREE MILE ISLAND 49-50, $70-71$ (1979) (personnel training); id. at 44, 68 (quality control); 1 SPECIAL INQUIRY GROUP, NU. CLEAR REGULATORY COMM'N, THREE MILE ISLAND 89 (1980) (operator training) [hereinafter cited as ROGOVIN REPORT]; 2 id. (pt. 1), at 44-50 (quality assurance).

16. See, e.g., 40 C.F.R. $\S 60$ (1983) (industry-by-industry new source performance standards under Clean Air Act); id. $\S \S 405-460$ (industry-by-industry effluent standards under Federal Water Pollution Control Act).

17. E.g., Atomic Energy Act of 1946, Pub. L. No. 79-585, § 3(b), 60 Stat. 755, 759 (1946), (authorization for in-house research) (current version codified at 42 U.S.C. \$§ 2052-2053 (1976)); id. \& 4(c), 60 Stat. at 759 (exclusive ownership of production facilities) (current version codified at 42 U.S.C. § 2061(a) (1976)); id. §5(a)(2), 60 Stat. at 760 (same for materials) (repealed by Act of Aug. 26, 1964, Pub. L. No. 88-489, § 4, 78 Stat. 603); id. § 6(a), 60 Stat. at 763 (authority for military research and production) (current version codified at 42 U.S.C. § 2121(a) (1976)).

18. See 42 U.S.C. \& 4332(C) (1976) (environmental impact statements). 
Congress did not instruct the NLRB to theorize about the behavior of management or explore new phenomena in the labor market. Nor did it ask the SEC to analyze the stochastic subtleties of speculative movements in securities prices. Even the Federal Communications Commission, at the cutting edge of technology, was limited in its responsibilities, ${ }^{19}$ with only implicit statutory encouragement to involve itself in research ${ }^{20}$ and none for direct involvement in development.

In sum, to assure air and water quality, the safety of complex systems, workplace health and safety, and the reliability of food and drugs, the modern agency must model ecological and economic systems, interpret and evaluate scientific data, and forecast the future. ${ }^{21}$ In so doing, agencies with a specified mission often take on responsibilities beyond those

19. Federal Communications Act of 1934 , Pub. L. No. 73-416, $\S 201$ (a), 48 Stat. 1064,1070 (authorization to order provision of service by common carriers) (current version codified at 47 U.S.C. $\S 201$ (a) (1976)); id. $\$ \S 201$ (b), 205(a), 48 Stat. at 1072 (set and enforce "just and reasonable" rates); id. $\S 213(\mathrm{~b}), 48$ Stat. at 1074 (value and inventory carrier property); id. $\S 214(\mathrm{a}), 48$ Stat. at 1075 (license interstate service); id. $\$ 309,48$ Stat. at 1085 (license radio stations).

20. Id. $\S 218,48$ Stat. at 1077 (authorizing FCC to inform itself of current technological developments); id. $\S 303(\mathrm{~g}), 48$ Stat. at 1082 (instructing FCC to study new uses of radio transmission).

21. See, e.g., Federal Food, Drug and Cosmetic Act, 21 U.S.C. § 346(a), (b) (1982) (authorizing FDA Administrator to establish zero tolerance level for pesticide if scientific data do not justify greater tolerance); Occupational Safety and Health Act of 1970, 29 U.S.C. \& 655(b)(5) (1976) (occupational exposure standards for toxic agents must take account of latest available scientific data, feasibility of standards, and past experience); Federal Insecticide, Fungicide and Rodenticide Act, 7 U.S.C. $\S$ $136 \mathrm{a}(\mathrm{c})(5)(\mathrm{C})(1982)$ (EPA registration of pesticide contingent on finding that its use will not have unreasonable adverse environmental effects); Resource Conservation and Recovery Act of 1976, 42 U.S.C. $\$ \S 6903(5), 6922-6923$ (1976) (defining "hazardous waste" as waste that may cause mortality or pose potential hazard, and instructing EPA to regulate generation of such wastes when they are in quantities sufficient to pose potential harm to human health); Safe Drinking Water Amendments of 1977, 42 U.S.C. $§ 300 j-1$ (c) (Supp. V 1981) (EPA instructed to submit report to Congress projecting future demand for drinking water and describing in detail problems to be resolved to assure adequate and dependable future supply); Toxic Substances Control Act, 15 U.S.C. $\$ \S 2603$ (a)(1)(A)(i), 2605(a) (1982) (directing EPA to regulate and authorize direct resting of chemicals that may present unreasonable risks to health); Consumer Product Safety Act, 15 U.S.C. $\$ \S 2051,2056,2061$ (1982) (CPSC to regulate consumer products to prevent unreasonable risks and imminent hazards); Federal Water Pollution Control Act Amendments of 1972, 33 U.S.C. \$ 1252(a) (1976) (EPA to propose comprehensive water pollution control strategies); id. $\S 1254(\mathrm{a})$ (water quality studies); id. $\$ 1254(\mathrm{~g})(2)$ (EPA Administrator instructed to forecast supply and demand of professionals needed to maintain water quality); id. § 1258 (demonstration projects in Great Lakes); id. § 1317 (1976 \& Supp. V 1981) (EPA to evaluate ecotoxicity of water pollutants); id. § 1326 (1976) (thermal effluent limitations to be based on anticipated ecological and environmental effects); Clean Air Act Amendments of 1977, 42 U.S.C. $\$ 7409$ (d)(2) (Supp. V 1981) (establishing scientific review body charged with advising EPA of probable effects of national ambient air quality standards); id. $\S 7411(\mathrm{f})(2)(\mathrm{B})$ (EPA to consider, in determining priorities for promulgating air quality standards for major stationary sources, extent to which pollution "may reasonably be anticipated to endanger public health or welfare"); $j d$. $\S$ 7521 (a)(1) (same for risks from motor vehicle emissions); id. $\$ 7620$ (construction of models aiding the prevention of air quality deterioration); Public Utility Regulatory Policies Act of 1978, 16 U.S.C. $\S$ 824j(a) (1982) (Federal Energy Regulatory Commission authorized to order "wheeling" of electric power transmission services upon predictions of improved energy conservation, energy efficiency, or reliability of power systems).

Courts have noted that prediction plays a central role in environmental decisions. See, e.g., NRDC v. EPA, 655 F.2d 318, 334-36 (D.C. Cir. 1981) (prediction as to durability of automobile filter); Minnesota v. NRC, 602 F.2d 412, 416-17 (D.C. Cir. 1979) (likelihood of solution for nuclear waste disposal problems). 
granted them by enabling legislation. ${ }^{22}$ This expansion of administrative power is due, in part, to the success of the environmental movement. ${ }^{23}$ Yet in leading us beyond the New Deal, environmentalists have shattered the old political equilibrium. By shifting the center of gravity of the administrative state from the articulation of social and economic goals to concern with the implications of new technology and scientific discovery, ${ }^{24}$ they have encouraged the use of sophisticated techniques distant from ordinary experience and blurred the boundaries of institutional authority, thereby reopening the question of how to assure effective independent oversight of technological decisions.

II.

If it were possible to separate the technical from the political, ethical, and legal, the New Deal's assumptions and the use of expertise that those assumptions entail might well go unquestioned. ${ }^{25}$ For if such separation

22. Under the pressure of the systemic philosophy of the National Environmental Policy Act, 42 U.S.C. $\$ \S 4321,4331-4332$ (1976), the Interstate Commerce Commission has estimated the effects of changes in freight rates on the volume of scrap metal recycling, see Aberdeen \& Rockfish R.R. v. Students Challenging Regulatory Agency Procedures, 422 U.S. 289, 300-02 (1975); the environmental implications of the activities of the Office of Management and Budget have been challenged, see Andrus v. Sierra Club, 442 U.S. 347 (1979); the Department of Interior has been ordered to consider possible nuclear power plant construction and changes in natural gas pricing before approving offshore oil exploration, see NRDC v. Morton, 458 F.2d 827, 837 (D.C. Cir. 1972), and the Nuclear Regulatory Commission (NRC) has considered the comparative health consequences and economics of nuclear and fossil-fuel based electricity production, see In re Public Serv. Co., 7 N.R.C. 179, 187 (1978); In re Tennessee Valley Auth., 5 N.R.C. 92, 102-03 (1977).

23. The success of the environmental movement may be read as a reaction to the New Deal's faith in expertise. In some respects, the reaction was extreme: Authors condemned whole technologies as dangerous, see, e.g., P. BRODEUR, THE ZAPPING OF AMERICA (1977) (health risks of radiofrequency and microwave radiation); H. CALDICOTT, NUCLEAR MADNESS (1978) (health risks of nuclear power). Yet the pressure of debate proved helpful. It led to reconsideration of the prevailing view that providing an adequate and reliable supply of electricity requires central power stations. See A. LovINS \& L. LOVINS, BRITTLE POWER 214-34 (1982). It sensitized the country to the implications of an unregulated cycle of chemical innovation, use, and disposal. And it led to the realization that in a technological era, there are subtle and serious costs associated with a thoroughgoing dependence on quantitative policy analysis. See B. COMMONER, THE POLITICS OF ENERGY 17, 85 (1979) (distortion of Project Independence Energy System model during Carter Administration).

24. But cf. Ackerman \& Hassler, Beyond the New Deal: Reply, 90 YALE L.J. 1412, 1414 (1981) (decrying congressional failure to shift attention from technological means for controlling air pollution to environmental ends defined in human, nontechnocratic terms).

25. The following discussion parallels in some respects Professor McGarity's analysis of separability issues. See McGarity, Substantive and Procedural Discretion in Administrative Resolution of Science Policy Questions: Regulating Carcinogens in EPA and OSHA, 67 GEO. L.J. 729 (1979). Professor McGarity argues that it is not possible to separate objectively the scientific and technological dimensions of regulatory questions raised by science, but not answerable using scientific methods, id. at 732, an argument consistent with mine, see infra pp. 1306-12. Yet our functional prescriptions differ sharply. McGarity favors a "result-oriented" jurisprudence in which agencies are given full power to decide non-separable issues. Id. at 781. I seek a balance among agencies and courts, see infra pp. 1320-23, and reject a model of special deference to regulatory decisions on the frontiers of science and technology, see infra pp. 1322-23, 1332. In my view, Professor McGarity effectively argues for a return to Landis' extra-deferential treatment of administrative decisions, rejecting Separability only to reassert it at a functional level. 
were workable, environmental decisions could be made in a simple twostep process. Scientists, engineers, or statisticians would first gather, compile, and analyze data, and legislators or administrative policymakers would then consider the first-stage results and come to ultimate findings. This two-step model preserves the traditional functional relationships within administrative law by creating special institutions that analyze controversial technical questions and report their findings to policymakers.

The history of unsuccessful attempts to distinguish fact from law ${ }^{26}$ suggests that separation may be an unattainable goal. ${ }^{27}$ Courts recognized long ago that mixed questions of fact and law pose special problems for the judicial system. ${ }^{28}$ Three different solutions emerged. The first claims that the behavior of courts provides a practical, if tautological, definition: Legal questions are those that judges choose to determine. ${ }^{2 \theta}$ The second takes the functional position that legal questions are those about which courts possess expertise, and therefore malses the normative claim that reviewing courts should only decide procedural issues that lie within judges' special competence. ${ }^{30}$ The third solution is substantive: It takes "facts" to

26. See, e.g., L. JAFFE, supra note 13, at 592-94; cf. Yee-Litt v. Richardson, 353 F. Supp. 996, 999-1000 (N.D. Cal.) (three judge court) (inherent difficulty in applying fact-policy distinction to welfare appeals leads to due process violation), aff'd sub nom. Carleson v. Yee-Litt, 412 U.S. 924 (1973).

27. Three distinct lines of Non-Separatist argument can be distinguished:

(1) A belief in the need to strengthen the authority of the executive branch so as to enable better management and more efficient settlement of technological disputes. Proposals for internal reform of the federal administrative agencies regularly express this view. See, e.g., COMM'N ON LAW AND THE ECONOMY, AM. BAR ASSOC., FEDERAL REGULATION: ROADS TO REFORM $79-88$ (1979); Cutler, Book Review, 96 HARV. L. REV. 545 (1982); Cutler \& Johnson, Regulation and the Political Process, 84 YALE L.J. 1395, 1414-17 (1975). See generally S. BREYER, REGULATION AND ITS REFORM 359-60 (1982) (describing proposals to give President power to reverse agency policy decisions).

(2) A belief that environmental disputes are best settled by informal negotiation, divorced from the formal constraints of the adversary process and insulated from the implicit restrictions governing scientific research. This view is prevalent in discussions of how to treat the unwanted side effects of familiar technologies. Managing non-nuclear hazardous wastes and choosing sites for dams are typical problems to which a negotiation approach has been applied. See L. BACOW \& M. WHEELER, ENVI. RONMENTAL DISPUTE RESOLUTION (forthcoming).

(3) A belief that existing institutions and institutional relationships should be redesigned to encourage greater cooperation among the legal and scientific communities. See Markey, Law and Science-Equal but Separate, 15 NAT. RESOURCES LAW. 619, 621-22 (1983). This view is usually expressed in environmental controversies involving advanced technologies, such as nuclear power and air pollution control.

The crucial distinction among Non-Separatists is the degree of belief they profess in the logical progression from the proposition that most environmental issues are Non-Separable, to the proposition that in practice all environmental controversies turn on "policy" questions, to the conclusion that science, and by implication, rational analysis itself, have little to contribute to the resolution of environmental problems. I reject this logic as a celebration of ignorance. Yet its importance as a factor in public debate cannot be denied. See Carter, Separatism and Skepticism, 92 YALE L.J. 1334, 1339-41 (1983).

28. See ICC v. Union Pac. R.R., 222 U.S. 541, 547-48 (1912).

29. See L. GREEN, JUDGE AND JURY 279 (1930).

30. "Our desire to have courts determine questions of law is related to a belief in their ... expertness with regard to such questions. It is from that very desire that the nature of questions of 
be natural phenomena that can be described without any knowledge of law, ${ }^{31}$ and it calls upon a reviewing court to assure itself that the decision under scrutiny is the result of reasoning from evidence, rather than the mere exercise of personal will. ${ }^{32}$ That the functional prescriptions these solutions entail are so different, and their reconciliation empirically so difficult, ${ }^{33}$ underlines the refractory character of the problem of separating fact from law.

Nonetheless, advocates of "science courts"-institutions specifically designed to deal with factual technical issues-adopt a hybrid of the second and third approaches. They believe that it is possible to separate, on analytic grounds, pure scientific and engineering judgments from political, normative, and legal judgments ${ }^{34}$ that can competently be made by appointed and elected officials. They further believe that Separation demands the creation of special fact-finding and fact-interpreting institutions. $^{\text {ss }}$ William Ruckelshaus, the Administrator of the Environmental

law emerges." J. LANDIS, supra note 3, at 152.

31. Sec, e.g., L. JAFFE, supra note 13 , at 548.

32. See id. at 596, 599 (discussing substantial evidence standard).

33. See, e.g., Brown, Fact and Law in Judicial Review, 56 HARv. L. REv. 899, 904-05 (1943) (no precise rule for distinguishing fact and law can be formulated, but there are general principles that explain outcomes of specific cases). Compare J. DICKINSON, ADMINISTRATIVE JUSTICE AND THE SUPREMACY OF LAW 55 (1927) (fact and law distinctions arbitrary) with Morris, Law and Fact, 55 HARV. L. REV. 1303, 1306 (1942) (fact and law form distinct categories).

34. In the following discussion, the term "technical" denotes putative scientific and engineering issues; the term "political" denotes putative legal, normative, and political issues.

35. E.g., Kantrowitz, Controlling Technology Democratically, 63 AM. SCIENTIST 505 (1975); Martin, The Proposed "Science Court," 75 MICH. L. REV. 1058 (1977); Mazur, Science Courts, 15 MINERVA 1 (1977); Task Force of the Presidential Advisory Group on Anticipated Advances in Science and Technology, The Science Court Experiment: An Interim Report, 193 SCIENCE 653 (1976) [hereinafter cited as Science Court Task Force]; Whitney, The Case for Creating a Special Environmental Court System, 14 WM. \& MARY L. REV. 473 (1973); Note, Procedures for Decisionmaking Under Conditions of Scientific Uncertainty: The Science Court Proposal, 16 HARV. J. ON LEGIS. 443 (1979); see also Casper, Technology Policy and Democracy, 194 SCIENCE 29 (1976) (disputing value of science court in broadly addressing technological controversies, but calling for use of public adversary process to illuminate decisionmaking). But see Abrams \& Berry, Mediation: A Better Alternative to Science Courts, BULl. ATOM. SCIENTISTS, Apr. 1977, at 50 (proposing proceeding in which parties and mediator publish a joint article that clarifies technological controversies by setting out the data, the initial position of the parties, and their final positions, and specifies any changes in the parties' positions or the formulation of the controversy induced by the process); Callen, The Science Court, 193 SCIENCE 950, 951 (1976) (science court proposals simplistic and dangerous: impossible to separate facts from values in technological controversies); Commoner, $A$ "Supreme Court" for Science?, 11 HOSP. PRAGTICE 125 (1976) (establishment of science court undesirable because it would give advice outside safeguards of peer review system and would institutionalize advisory system that lags behind public in recognizing importance of environmental issues); Hammond \& Adelman, Science, Values, and Human Judgment, 194 SCIENCE 389, 391-93 (1976) (science court concept confuses results of a scientific advetsary process with scientific judgments; preferable to use "person-oriented" approach in which explicit social value judgments of elected officials are weighed and numerically combined with explicit scientific judgments of experts to reach ultimate decisions); Lipson, Technical Issues and the Adversary Process, 194 SCIENCE 890 (1976) (science court proposal overemphasizes truthfinding value of adversary process; decisions would inherently be value-laden); Sofaer, The Science Court: Unscientific and Unsound, 9 ENVTL. L. 1, 11 (1978) (assumption that scientists' predictive judgments can be separated from personal value choices gives unjustifiable aura of neutrality to proposed science court). 
Protection Agency (EPA), takes a similar Separatist position. He argues for a sharp distinction between two different governmental functions: "risk assessment," the objective, scientific activity that establishes the probabilities and consequences of exposure to chemicals and radiation; and "risk management," the core administrative activity, which should be governed by a common statutory formula for weighing risks against benefits in reaching regulatory decisions. ${ }^{38}$ The importance of the issues and the weight of opinion behind the Separability thesis suggest that the thesis deserves both analytic and empirical tests. If the world is truly Separable, it should be possible logically to distinguish the technical and legal dimensions of environmental issues, and these distinctions should be manifest in the actual performance of institutions.

The Separatist argument is threefold. First, Separatists assert that it is possible, within the context of environmental controversies, to identify certain issues as "scientific"sz and assign them to the appropriate nonpolitical institutions-if necessary creating institutions for that purpose. Second, Separatists claim that this assignment is responsive to democratic practices, in that once Separability has been achieved and purely technical questions have been answered, policy questions can be resolved by properly elected or appointed officials. ${ }^{38}$ Third, Separatists argue that the advantages of open technological decisions can be enjoyed only in the context

36. See Ruckelshaus, Science, Risks and Public Policy, 221 ScIENCE 1026 (1983) (address to the National Academy of Sciences, Washington, D.C.). Ruckelshaus responds to a recent report of a panel of the National Research Council, see COMMITTEE ON THE INSTITUTIONAL MEANS FOR ASSESSMENT OF RISKS TO PUBLIC HEALTH, NATIONAL RESEARCH COUNCIL, RISK ASSESSMENT IN THE FED. ERAL GOVERNMENT (1983) [hereinafter cited as RISK MGMT. REP.], that responds in turn to a congressional inquiry whether "objective" risk assessment can be separated institutionally from "public and social policy decisions." Id. at 140 . The panel urges regulatory agencies to maintain a "clear conceptual distinction" between risk assessment and risk management. Id. at 7 . This suggests to Ruckelshaus that policy considerations need not and should not enter risk assessment. See Ruckelshaus, supra, at 1027-28 (if public suspects that policy considerations influence risk assessment, public confidence in regulatory decisions erodes). The National Research Council panel does not, however, argue that sharp conceptual distinctions between technical and political issues can be drawn. Rather, under the panel's definitions of those terms, risk management and risk assessment cut across science and policy. See RISK MGMT. REP., supra, at 33, 36-37, 48-49, 76-77, 142-43, 166-67.

Although the National Research Council panel and this Article share the view that technical and nontechnical questions are not separable, there are important differences between the two approaches. In general, the Report stresses functional-as distinct from substantive-separation of policy from science, see RISK MGMT. REP., supra, at 153-54, while this Article fully accepts substantive NonSeparability and calls for institutional innovations that encourage a controlled mixing of technical and political roles, see infra pp. 1328-30.

37. Kantrowitz, supra note 35, at 506-07; Martin, supra note 35, at 1064; Science Court Task Force, supra note 35, at 654; cf. Mazur, supra note 35, at 11 (fact-value separation not fully possible; science court can and should attempt to resolve only those statements falsifiable using empirical data).

38. Kantrowitz, supra note $\mathbf{3 5}$, at $\mathbf{5 0 5}$ (unthinkable in democratic society that scientists would be endowed with authority to assume full moral responsibility for science's social impact); Martin, supra note 35 , at 1064 (science court proposal allocates scientific questions to experts, policy questions to public representatives); Science Court Task Force, supra note 35, at 653 (establishment of science court will allow ultimate social value questions to be settled by government or directly by voters). 


\section{Environmental Decisionmaking}

of an adversary process. ${ }^{39}$

These arguments have undeniable force. If the technical can be distinguished in practice from the legal and ethical, the principles of democratic government demand that Separation be enforced in order that properly chosen public officials make the legal, political, and ethical decisions that we have placed in their care. For if these distinctions go unenforced as technological decisions proliferate, experts gradually will assume greater roles in policymaking, boundaries of institutional authority will blur, and participatory government will be threatened. In a Separatist world, a powerful justification thus emerges for preserving the existing institutional balance, while creating new institutions that provide the necessary technical expertise.

Yet before establishing such institutions, a serious examination of assertedly separable issues is in order. It is true that there are scientific and engineering problems whose answers are central to environmental decisions and yet free of legal and ethical content. Given adequately specified assumptions, solutions of the partial differential equations describing the diffusion of air pollutants can be agreed upon, even when they bear upon the form and application of rules and procedures under the Clean Air Act-rules and procedures that affect almost every domestic industry. And it is possible in principle to construct models that enable estimation, apart from any ethical and legal considerations, of the atmospheric concentration of substances that can degrade the ozone layer or raise the global mean surface temperature. But the difficult environmental cases that regularly confront agencies and courts often turn on evidence of actual harm that is not immediately compelling-evidence based upon complex models whose validity cannot yet be tested directly; or upon statistical tests applied at the limits of detectability, in the absence of knowledge about the biological mechanisms by which harm may be caused. ${ }^{40}$ Given the tenuous

39. Casper, supra note 35, at 32-33 (public adversary processes will: (1) allow technical experts to present analyses of social and political implications of new technology in institutional framework that does not presuppose experts' objectivity; (2) create genuine debate among experts, rather than encourage consensus of opinion; (3) create tradition of public dialogue that will combat secrecy and make whistleblowing unnecessary); Kantrowitz, supra note 35, at 507 (formal adversary process with scientifically sophisticated advocates and judges will "optimize objectivity" and lead to judgments that "forcgo . . . moral or political stands"); Martin, supra note 35, at 1074 (central purpose of science court proposal is to employ adversary process to uncover truth); Science Court Task Force, supra note 35, at 653 (procedures modeled on formal legal adjudication will enable emergence of "defensible, credible, technical bases for urgent policy decisions"). But see Sofaer, supra note 35, at 20-21 (adversary system places great weight on personal and verbal abilities of advocates; therefore, it is ill-suited to produce scientifically acceptable decisions).

40. Environmental decisions would be very different, though hardly easier if, for example, mechanisms for carcinogenesis were fully understood. For if so, while the demand for assessments of risk of the precise sort we now debate would gradually fade away, discussion would focus instead on whether the causal notions inherent in traditional formulas for legal and ethical responsibilities are transferable to biomedical and engineering contexts in which probabilities play important roles. 
nature of the technical evidence and the uncertainties about how actual injuries may occur, environmental controversies cannot be split into technical and legal parts. Environmental decisions then ultimately turn not on the substance of scientific questions, but on the procedures by which the significance of scientific evidence is evaluated-procedures integral, though in quite different senses, both to the administrative process and to scientific research.

Consider the hypothesis that workers exposed over many years to airborne benzene in concentrations of ten parts per million are twice as likely to suffer from leukemia as persons in the general population. ${ }^{41}$ Separatists would characterize this hypothesis as a "scientific" question properly addressed by a technical advisory body. ${ }^{42}$ Specifying the dose-incidence relationship ${ }^{4}$ for leukemia at low levels of benzene exposure is not, however, an ordinary scientific task. We do not yet know how leukemia is induced. Therefore, to infer a relationship between chronic low-level benzene exposure and leukemia is to make an assertion about statistical correlations, rather than biological mechanisms. Moreover, although statistical studies suggest that exposure to high concentrations of benzene, perhaps in combination with other factors, is associated with a significantly increased risk of leukemia, ${ }^{44}$ there are no precise incidence data at exposures as low as ten parts per million. ${ }^{45}$ The hypothesis that low-dose exposure to benzene significantly increases the risk of leukemia is therefore settled for regulatory purposes by weighing fragmentary, uncertain, and often contradictory pieces of epidemiological evidence bearing upon the occurrence of leukemia in small numbers of workers. ${ }^{46}$

That this evidence is far from perfect does not vitiate the usefulness of detailed analysis. Experts can develop, perform, and analyze epidemiological surveys and animal experiments bearing upon toxicity. Given data from these surveys and experiments, they can formulate statistical tests and in principle control the "Type I" error of rejecting the hypothesis that

41. Cr. Industrial Union Dep't v. American Petroleum Inst., 448 U.S. 607 (1980) (plurality opinion) (Benzene) (invalidating OSHA's proposed reduction of benzene exposure standard from 10 parts per million to 1 part per million); see id. at $618 \mathrm{n} .9$ (first large-scale epidemiological study of benzene and leukemia found twofold increase in leukemia rate of exposed workers over rate in general population).

42. See Martin, supra note 35, at 1079; Mazur, supra note 35, at 10-11. But see McGarity, supra note 25 , at $749-50$ (to interpret cancer-related agency policy decisions as pure factual findings puts intolerable strain on traditional Separatist model of court-agency relationship).

43. The dose-incidence relations referred to here specify the percentage of an exposed population expected to suffer disease, given a specified exposure level.

44. See, e.g., COMM. ON TOXICOLOGY, NATIONAL RESEARCH COUNCIL-NATIONAL ACADEMY OF SCIENCES, HEALTH EFFECTS OF BENZENE 9-15 (1976).

45. See Industrial Union Dep't v. American Petroleum Inst., 448 U.S. 607, 699-702 \& nn.23-24

(1980) (Marshall, J., dissenting).

46. See 448 U.S. at 618 n.9, 619-20 n.12 (plurality opinion). 
"substance $X$ leads to disease $D$ at concentration $Y$ with probability $P$ " when this hypothesis is true, or the "Type II" error of accepting this hypothesis when false. ${ }^{47}$ But in this process, a central question is not addressed: How should one specify the sizes of the environmental mistakes society is willing to tolerate? That this question remains makes clear that standards of proof for evaluating the results of statistical tests or extrapolations from animal experiments ${ }^{\mathbf{4 8}}$ are critical to environmental decisions. $^{48}$

Setting a standard of proof is at once a device for controlling error and for assuring fairness. ${ }^{\text {s0 }}$ It requires, for example, an assessment of the seriousness of the risk in question. ${ }^{.1}$ We regret any large-scale damage to public health or the environment. But it is nevertheless true that we are more willing to tolerate the risk of an error that causes the extinction of snail darters or bowhead whales than one that endangers human lives. ${ }^{\mathbf{5 2}}$ This distinction will be reflected in different standards of proof for evaluating proposals to lease offshore lands for oil exploration and for approving new food additives. ${ }^{\text {s3 }}$

Setting a standard of proof requires, moreover, an appreciation of the difficulties of reaching definitive risk estimates. For example, a standard of proof that calls for unrealistically small "Type I" and "Type II" errors

47. See, e.g., P. BICKEL \& K. DOKSUM, MATHEMATICAL STATISTICS 163-71 (1977); H. CRAMER, MATHEMATICAL METHODS OF STATISTICS 527-28 (1946).

48. For a recent attempt to set out a general theory on which such standards could be based, see DuMouchel \& Harris, Bayes Methods for Combining the Results of Cancer Studies in Humans and Other Species, 78 J. AM. STATISTICAL ASS'N 293 (1983).

49. See Industrial Union Dep't v. American Petroleum Inst., 448 U.S. 607, 652 (1980) (plurality opinion); Hercules, Inc. v. EPA, 598 F.2d 91, 107 \& n.26 (D.C. Cir. 1978); International Harvester Co. v. Ruckelshaus, 478 F.2d 615, 642-43 (D.C. Cir. 1973).

50. See In re Winship, 397 U.S. 358, 370-71 (1970) (Harlan, J., concurring); Leventhal, Environmental Decisionmaking and the Role of the Courts, 122 U. PA. L. REV. 509, 536 (1974).

51. In more traditional terms, formulation of a standard of proof demands sensitivity to the relative importance of the interests at stake. See, e.g., In re Winship, 397 U.S. 358, 370-72 (1970) (Harlan, J., concurring) (liberty interest requires proof of criminal guilt beyond a reasonable doubt); International Harvester Co. v. Ruckelshaus, 478 F.2d 615, 642 (D.C. Cir. 1973) (standard of proof must take into account nature and consequences of risks of error); Jaffe, Administrative Law: Burden of Proof and Scope of Review, 79 HARV. L. REV. 914, 919 (1966) (when administrative action would result in serious consequences for individuals, justice may be served by increased procedural protections).

52. Although protection of the snail darter under the Endangered Species Act of 1973, 16 U.S.C. $\S \S 1531-1543$ (1982), delayed the Tellico Dam project, see TVA v. Hill, 437 U.S. 153 (1978), Congress later exempted the project from the Act, see Energy \& Water Development Appropriation Act of 1980, Pub. L. No. 96-69, 93 Stat. 437, 449-50 (1979), and the dam is now complete.

53. Compare Environmental Defense Fund, Inc. v. EPA, 598 F.2d 62, 88 (D.C. Cir. 1978) (emphasizing statutory and precedential support for less stringent standard of proof in administrative decision to prohibit commercial use of suspect carcinogen) with Houck, The "Institutionalization of Caution" Under $\& 7$ of the Endangered Species Act: What Do You Do When You Don't Know?, 12 ENVTL. L. REP. 15,001, 15,001 \& n.4 (1982) (pointing out that under standards of Endangered Species Act for weighing eviderce of threats to species survival, of 4500 consultations under the Act conducted from 1973 to 1978, only three led to litigation, and all three projects subsequently were completed). 
of $0.1 \%$ in setting a maximum occupational exposure of ten parts per million of benzene in air is no standard at all. It will be ignored in practice, to be replaced by other implicit rules that make regulatory decisions easier. Moreover, a standard of proof cannot reasonably be set without an appreciation of its consequences for the perceived fairness of the decisionmaking process. However carefully formulated, the hypothetical standard that accepts a greater margin for the error of incorrectly concluding that a substance poses negligible occupational risks when the workers at risk are poor and uneducated raises serious questions about the integrity of the resulting decisions. In sum, no one sensitive to the full implications of the endeavor can set a standard of proof for determining the riskiness of human exposure to a hazardous substance while neglecting either political or technical considerations. In that sense, setting a standard of proof is a non-Separable task. ${ }^{54}$

One might suppose that there are common objectives in the weighing of evidence for pure scientific purposes and for regulatory purposes. In turn, these commonalities-allowing for the technical problems of adapting scientific language to a regulatory context-might assure that expert bodies can make judgments that are both scientifically defensible and useful in practical regulation. But this argument fails to confront important functional distinctions between scientific and legal evidence. Scientific evidence principally serves to define the limits of knowledge and help set directions for further work. Observing the remnants of the primordial universe, proving an outstanding conjecture in computation theory, or discovering the functions of a retrovirus, may provide spectacular confirmation of the vitality of science, enrich the researchers, or cure the sick. But these are not scientific concerns. The integrity of each scientific community depends on the limited use of the results of discovery to illuminate the intellectual future. Once the process of weighing evidence is set in the context of a societal decision, however, the direct impact of the evaluation does not fall only on the scientific community. Claims of right or of compensation for injury must then be addressed, and these evoke larger purposes: the objectives of protecting individual rights, assuring fairness, and preserving the integrity of the legal system. The same normative arguments that underlie Separatist theory tell us that these are not questions to which technical experts qua experts ought to speak.

Actual experience in resolving environmental controversies demonstrates that however attractive Separability is in theory, it has not been achieved in fact. Experts have not been restricted to technical matters, nor have generalist decisionmakers restricted themselves to legal and norma-

54. See McGarity, supra note 25 , at $748-49$. 
tive issues. Consider the widely followed decision of the United States Court of Appeals for the Eighth Circuit in Reserve Mining Co. v. EPA, ${ }^{\text {s5 }}$ in which environmental groups and local, state, and federal agencies challenged the dumping of tailings from iron mining into Lake Superior. The plaintiffs argued that a low, though measurable, concentration of asbestiform fibers in local drinking water-contamination presumably resulting from the Reserve Mining Company's operations ${ }^{86}$-endangered the citizens of Duluth, Minnesota.

Under a Separatist model, the standard of proof that such a risk has legal significance is set by statute, or failing that, by a court. ${ }^{57}$ Moreover, in a Separatist world, judges do not make technical findings. In Reserve Mining, however, these limits were not respected. The federal district court retained its own expert medical witness to help it understand the evidence. Separatist theory notwithstanding, the court's expert formulated a standard of proof with immediate legal implications. In evaluating the risks to Duluth residents, he distinguished between "medical" and "scientific" proof. ${ }^{58} \mathrm{He}$ argued that scientific conclusions recognized as truth must meet numerical standards that are generally high, ${ }^{80}$ and that proof of a medical risk requires a less stringent standard, based, as he put it, upon erring "on the side of what is best for the greatest number." court of appeals accepted this argument, concluding that the asbestos contaminant "gives rise to a reasonable medical concern," "creates some health risk," and should be removed. ${ }^{81}$ The Reserve Mining court did not confine itself to logical inferences based upon legal arguments. Addressing a dose-incidence problem similar to the one faced in Industrial Union Department v. American Petroleum Institute (Benzene), ${ }^{62}$ the Eighth Gircuit held that there was no "scientific or medical basis" to conclude that the residents of Duluth "experience[d] an excess rate of cancer attributable to Reserve's discharge." 83

Ethyl Corp. v. EPA, ${ }^{64}$ which upheld regulations requiring a phaseout of lead additives in gasoline, provides another example of an excursion by a federal court of appeals into a technical universe. The arguments that people are harmed by exposure to airborne lead rely in part upon bio-

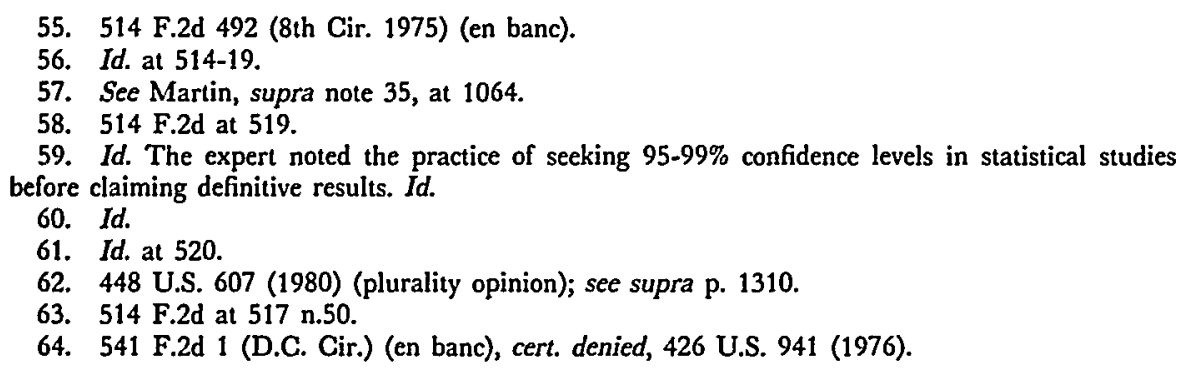


chemistry ${ }^{65}$ However, as in Reserve Mining, more persuasive than the biochemical evidence for the Ethyl court and the EPA was a body of epidemiological evidence bearing upon the health effects of lead at air concentrations commonly found in modern urban environments-levels much lower than those at which the classic symptoms of lead poisoning are observed. ${ }^{66}$

The epidemiological evidence of harm was ambiguous. A major study of blood lead levels in seven major cities found no demonstrable association between atmospheric lead levels presumably resulting from gasoline combustion and average lead levels in the blood of local residents. ${ }^{67}$ The EPA nevertheless decided to order the phaseout of the additives. In the agency's view, the lack of demonstrable environmental correlations in the seven cities study was outweighed by positive correlations detected in other studies. ${ }^{68}$ The D.C. Circuit upheld EPA's position, ${ }^{68}$ concluding that the agency had reasonably preferred the results of studies showing non-zero effects of low-level atmospheric lead, particularly in children living in city centers. ${ }^{70}$ In situations with high uncertainty, said the court, the error of finding zero effect when an effect does exist is more probable than the error of labeling a harmless substance as toxic. ${ }^{\text {11 }}$

Furthermore, as in Reserve Mining, the Ethyl majority reached its own conclusions regarding issues that would be viewed as technical in a Separable world. By applying empirical data on blood lead levels following exposure to airborne lead, the court found that lead emissions in the atmosphere due to gasoline combustion "can make a significant contribution to blood lead levels" in the general population. ${ }^{72}$ The court criticized the lack of controls on climatic conditions in epidemiological studies. ${ }^{73}$ It also reached its own judgment on the relative weight that should be accorded to the various epidemiologic and clinical studies. ${ }^{74}$

EthyPs conclusion regarding the relative significance of positive and negative epidemiological evidence turns in effect not only on the court's

65. See J. HARRIS \& R. KELlERMEYER, THE RED CELl 35-43 (rev. ed. 1970).

66. At the time Ethyl was decided, typical mean urban atmospheric lead levels were roughly 500 times lower than levels at which lead poisoning becomes clinically apparent. COMMM. ON BIOLOGICAL EFFECTS OF ATMOSPHERIC POLLUTANTS, NATIONAL ACADEMY OF SCIENCES, LEAD: AIRBORNE LEAD IN PERSPECTIVE 21-22, 74 (1972).

67. Tepper \& Levin, A Survey of Air and Population Lead Levels in Selected American Communities, reproduced in Jt. App. at 840, Ethyl Corp. v. EPA, 541 F.2d 1 (D.C. Cir.) (en banc), cert. denied, 426 U.S. 941 (1976). The Tepper and Levin study was jointly sponsored by EPA and the petroleum, lead, and zinc industries, see Jt. App. at 841, Ethyl.

68. See Ethyl, 541 F.2d at 57-61 (App. A).

69. Id. at 41 .

70. Id. at $40,43-46$.

71. Id. at 41 (citing D. Clark \& B. MaGMahon, Preventive Medicine 100 (1967)).

72. Id. at 55 .

73. Id. at 57 n.4.

74. Id. at 59, 63. 
specification of the relative sizes of Type I and Type II errors, ${ }^{78}$ but also on a general characterization of the ratio of correct to incorrect results in a particular field of research. A generalization of that kind carries the court well beyond the boundaries of judicial authority envisioned in Separatist theory. Such an exegesis can be justified only by reference to the details of the underlying biology and the relevant epidemiologic practices. Moreover, the court's critique and evaluation of the epidemiologic and clinical evidence directly answers the assertedly Separable dose-incidence question. ${ }^{28}$

In exploring technical issues in depth, Ethyl and Reserve Mining are not unique. In Texas v. EPA, ${ }^{77}$ a Fifth Circuit panel examined the details of a model of regional distribution of air pollutants central to Texas' State Implementation Plan under the Clean Air Act. The panel made purely technical inferences, ${ }^{78}$ in particular, it recalculated the figures that supported the state's estimates of regional photochemical oxidant concentrations. ${ }^{79}$ Similarly, in Union of Concerned Scientists v. Atomic Energy Commission, ${ }^{80}$ the D.C. Circuit considered in detail an environmental group's attacks on the computer model used by the Atomic Energy Commission (AEC) in determining the effectiveness of emergency core cooling systems (ECCSs) for commercial nuclear reactors ${ }^{81}$ and on the AEC's characterization of the largest feasible reactor accident against which the ECCS must guard. ${ }^{82}$ Recognizing the unusual technical aspects of the case $^{83}$ the court considered methodological distinctions that emerged from the AEC's computer simulations ${ }^{84}$ and attempted to reconcile the safety goals incorporated in the Commission's reactor siting policy with the accident categorization incorporated in the ECCS acceptance criteria. ${ }^{85}$ In International Harvester Co. v. Ruckelshaus, ${ }^{88}$ Judge Leventhal, over the Separatist objections of Judge Bazelon, ${ }^{87}$ analyzed in detail the results of tests of the effectiveness of catalytic converters for motor vehicle exhaust systems. ${ }^{88}$ His discussion makes clear that the technical and legal aspects

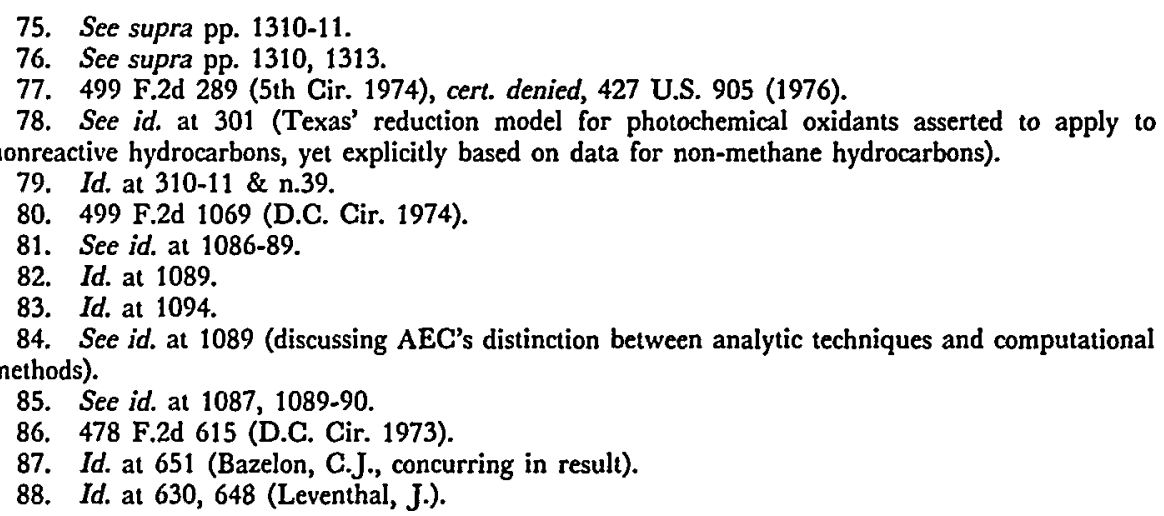


of the analysis intertwine. ${ }^{89}$ In Natural Resources Defense Council, Inc. v. NRC (Vermont Yankee III), ${ }^{\text {o0 }}$ Judge Bazelon, eschewing his Separatist procedural approach, ${ }^{91}$ examined in detail the Nuclear Regulatory Commission's (NRC's) evaluation of the risks of geologic disposal of nuclear wastes and found the Commission's treatment of the uncertainties in these risks deficient. ${ }^{92}$

This discussion does not suggest that the federal courts have acted improperly in reviewing environmental decisions. While the cases discussed above display unusual functional relationships among courts, agencies, and experts, they do not conflict with accepted judicial practices. Judges may properly reach a considered judgment that a court should, even unaided, take the inferential leap from scientific argument to legal conception. ${ }^{93}$ These cases illustrate instead the evolutionary process by which science is gradually and haltingly assimilated into law. ${ }^{94}$ They demonstrate that the distinction between scientific and legal issues is arbitrary and unworkable. The questions raised are deeper than whether useful distinctions can be drawn between technical and legal matters. Rather, as in the New Deal era, the modern environmental controversy challenges us to shape the changing roles of institutions.

89. Cf. Cabinet Mountains Wilderness v. Peterson, 510 F. Supp. 1186, 1189 (D.D.C. 1981) (where Congress has not directed, court will not substitute its views on environmental controversy in which subjective value judgments intertwine with scientific data).

90. 685 F.2d 459 (D.C. Cir. 1982), rev'd sub nom. Baltimore Gas \& Elec. v. NRDC, 103 S. Ct. 2246 (1983).

91. Compare 685 F.2d at 478-81 (Bazelon, J.) (finding NRC zero-risk conclusion represents "self-evident error in judgment") and id. at 481-86 (holding zero-risk conclusion improperly excludes uncertain environmental costs of nuclear waste disposal from consideration in individual reactor licensing) with International Harvester Co. v. Ruckelshaus, 478 F.2d 615, 650-53 (D.C. Cir. 1973) (Bazelon, C.J., concurring in result) (denying legality and utility of judicial exploration of technical intricacies of agency decisions and urging instead judicial establishment of procedural guidelines).

92. See 685 F.2d at $478-86$.

93. See Korn, Law, Fact, and Science in the Courts, 66 CoLUM. L. REv. 1080, 1100 (1966); cf. L. JAFFE, supra note 13, at 613 ("areas of expertness . . . are inextricably woven into the whole fabric of judgment").

94. The tentative nature of the process is perhaps clearest in criminal law. Compare United States v. Williams, 583 F.2d 1194 (2d Cir. 1978) (voiceprint cvidence admissible) with United States v. Alexander, 526 F.2d 161 (8th Cir. 1975) (voiceprint evidence inadmissible) and United States v. Addison, 498 F.2d 741 (D.C. Cir. 1974) (same). Administrative law provides similar evidence of evolutionary change. For example, as knowledge increases, different standards of proof may become applicable to the same agency action. See Texas v. EPA, 499 F.2d 289, 301 n.16 (5th Cir. 1974), cert. denied, 427 U.S. 905 (1976); see also Miller \& Barron, The Supreme Court, the Adversary System and the Flow of Information to the Justices: A Preliminary Inquiry, 61 VA. L. REV. 1187, 1187-91 (1975) (contrasting traditional Blackstonian model of information flow to court with informal flow to Supreme Court in actual cases). For discussions of the assimilation process, see Gellhorn, The Law's Demand for Both Stability and Change: The Legislative and Administrative Response, 17 VAND. L. REV. 91 (1963); Giannelli, The Admissibility of Novel Scientific Evidence. Frye v. United States, a Half Century Later, 80 COLUM. L. REV, 1197 (1980). 
III.

The failure of forms of Separability based either upon a substantive distinction between fact and law, or upon a normative restriction on the scope of judicial review, threatens the traditional structure of administrative law. Yet this structure may be preserved in other ways. An alternative model builds in a different way upon the functional and normative distinctions between fact-finding and lawmaking. ${ }^{95}$ This model gives a special interpretation to agency predictions based upon evidence on the frontiers of science and technology. It views these predictions as policy judgments relatively insulated from judicial oversight. ${ }^{98}$ In addition to their "ordinary" legal and factual dimensions, environmental decisions are taken in this alternative to have a characteristic core involving uncertain scientific evidence and specification of the maximum risks society will tolerate. ${ }^{87}$ Under the model, the responsibility for dealing with this core is assigned solely to administrative policymakers.

The deferential approach to "quasi-legislative" policymaking reflects historical practice ${ }^{98}$ and is widely followed. ${ }^{99}$ In principle, it enables the flexible response to scientific and technological change that Frankfurter envisioned. ${ }^{100}$ For as discovery and innovation proceed, the model of deference to administrative predictions can adjust the boundary between "ordinary" fact-finding and "quasi-legislative" judgment and thereby alter the functional relationships among institutions. Whether such a dynamic approach will succeed is an open question. It remains to be seen whether as agencies grow more sophisticated in facing reviewing courts, they defeat

95. See J. LANDIS, supra note 3 , at 152 .

96. See, e.g., Baltimore Gas \& Elec. Co. v. NRDC, 103 S. Ct. 2246, 2256, 4682 (1983) (Vermont Yankee IV) (zero-release assumption for nuclear waste depositories within Commission's discretion); Environmental Defense Fund v. EPA, 598 F.2d 62, 83-84 \& n.78 (D.C. Cir. 1978) (deferring to EPA's decision to regulate "less chlorinated" PCBs); Industrial Union Dep't v. Hodgson, 499 F.2d 467, 474-75 \& n.18 (D.C. Cir. 1974) (determination of tolerable level of asbestos dust left to Secretary).

97. See Comment, Implementing the National Environmental Policy Act Through Rulemaking, 126 U. PA. L. REV. 148, 161 (1977).

98. See, e.g., Humphrey's Executor v. United States, 295 U.S. 602, 628-29 (1935) (denying President's power to remove FTC commissioner, on grounds that Commission acts as quasi-legislative body); Prentis v. Atlantic Coastline Co., 211 U.S. 210, 226 (1908) (Holmes, J.) (upholding ratemaking decision of state commission as legislative act).

99. Indeed, the Court has effectively elevated the deference model to a higher status, forbidding as a violation of the bicameral and presentation requirements, U.S. CONST. art. I, $\S 7$, cls. 2-3, Congress' attempts to manage its delegation of authority in a complex society through the use of a veto power over administrative actions. See INS v. Chadha, 103 S. Ct. 2764, 2804 (1983) (White, J., dissenting). Chadha may well contribute to the ever-enlarging sphere of executive autonomy. Yet in an era in which agency regulations have been given the formal imprimatur of legislation, see Schweiker v. Gray Panthers, 453 U.S. 34, $43-44$ (1981), and high technology tends to isolate agency decisions from review, see infra pp. 1325-26, restoring the balance of power among institutions is an objective that deserves first priority.

100. See supra p. 1300. 
the adaptive process, increasing their discretionary powers by drawing more of the real substance of decisions into a realm that plausibly can be described as the scientific and technological frontier. ${ }^{101}$

The recent stages of the phoenix-like Vermont Yankee litigation ${ }^{102}$ provide some insight into the desirability of special judicial deference to agency predictions. The facts merit a brief review. ${ }^{103}$ In the military phase of the atomic energy program, experts recognized that, as a result of their toxicity, reactor wastes demand special disposal measures. ${ }^{104}$ Yet no disposal technology was created. Nor did Congress give the AEC, or later the commercial nuclear industry, incentives to find solutions to the waste problem. ${ }^{108}$ In 1972, the AEC instituted a generic rulemaking ${ }^{108}$ to decide how its boards hearing individual reactor licensing proceedings should treat the storage and disposal of spent fuel. On the basis of this rulemaking, the NRG, which assumed the AEC's regulatory responsibilities during the fuel cycle hearings, ${ }^{107}$ concluded that burial of high-level and transuranic wastes would not result in the release of toxic materials. The Commission summarized its conclusions in a table showing the NRC staff's numerical estimates of the environmental effects of the nuclear fuel cycle. ${ }^{108}$ This table omits, however, any estimate of the leakage of toxic

101. One commentator anticipates this shift in response to any review process that insulates an area of expertise from external oversight. See McGarity, supra note 25, at 750; see also New York v. United States, 342 U.S. 882, 884 (1951) (Douglas, J., dissenting) ("Unless we make the requirements for administrative actions strict and demanding, expertise, the strength of modern government, can become a monster . . . with no practical limits on its discretion."), cited with approval in Motor Vehicle Mfrs. Ass'n v. State Farm Mut. Auto Ins. Co., 103 S. Ct. 2856, 2869 (1983); Wuillamey v. Werblin, 364 F. Supp. 237, 241 (D.N.J. 1973) (technical expertise needed to reach air quality finding renders agency decision unassailable in a court).

More generally, several commentators have called attention to the increasing complexity of environmental litigation, caused by the growing sophistication of the major actors. See Rabin, Lawyers for Social Change: Perspectives on Public Interest Law, 28 STAN. L. REV. 207, 240-41 (1976); Yellin, High Technology and the Courts: Nuclear Power and the Need for Institutional Reform, 94 HARV. L. REV. 489,553 n.386 (1981).

102. See Natural Resources Defense Council, Inc. (NRDC) v. NRC, 547 F.2d 633 (D.C. Cir. 1976) (Vermont Yankee 1), rev'd in part and remanded sub nom. Vermont Yankee Nuclear Power Corp. v. NRDG, 435 U.S. 519 (1978) (Vermont Yankee II), on remand, NRDG v. NRC, 685 F.2d 459 (D.C. Cir. 1982) (Vermont Yankee III), rev'd sub nom. Baltimore Gas \& Elec. Co. v. NRDG, 103 S.Ct. 2246 (1983) (Vermont Yankee IV).

103. For a more extensive view of the substantive issues, see Yellin, supra note 101, at 531-49. For discussions of the procedural aspects of Vermont Yankee $I$ and Vermont Yankee II, see Byse, Vermont Yankee and the Evolution of Administrative Procedure: $A$ Somewhat Different View, 91 HaRv. L. REV. 1823 (1978); Stewart, Vermont Yankee and the Evolution of Administrative Procedure, 91 HARV. L. REV. 1805 (1978).

104. See, e.g., U.S. ATOMIC ENERGY COMM'N, RePORT WASH-88: ProceEdings OF THE REACTOR SAFEGUARD COMMITTEE 34 (1948) (summarizing meetings of June 14-16, 1948).

105. Cf. M. WILRICH \& R. LESTER, RADIOACTIVE WASTE 121 (1977) (noting lack of comprehensive plans for regulating nuclear wastes and for long-term waste management).

106. Environmental Effects of the Uranium Fuel Cycle No. RM.-50-3 (AEC 1972-74) (first phase of fuel cycle rulemaking).

107. See Energy Reorganization Act of 1974, 42 U.S.C. $\$ \S 5801-5879,5891$ (Supp. V 1981).

108. 39 Fed. Reg. 14,188, 14,191 (1974) (table S-3). 
wastes from permanent disposal facilities. Hearing boards considering reactor licensing applications therefore did not take into account in their cost-benefit balancing the uncertain environmental costs associated with the development and subsequent operation of geologic nuclear waste repositories. ${ }^{108}$

In Natural Resources Defense Council, Inc. (NRDC) v. NRC (Vermont Yankee $I),{ }^{110}$ environmental groups successfully challenged the fuel cycle rule. Judge Bazelon, writing for the D.C. Circuit, set aside and remanded the Commission's licensing decisions on mixed procedural and substantive grounds. ${ }^{111}$ The Supreme Court reversed in a strongly worded unanimous opinion. ${ }^{112}$ The Court read the lower court's decision as an improper attempt to restructure the agency's internal decisionmaking procedures, ${ }^{113}$ but left the door open for further judicial review of the adequacy of the administrative record. ${ }^{114}$ In the third phase of Vermont Yan$k e e,{ }^{115}$ the NRC had once again promulgated a fuel cycle rule. ${ }^{116}$ Again the NRDC challenged its validity. And again the D.C. Circuit, speaking through Judge Bazelon, invalidated the Commission's action, ${ }^{117}$ this time on explicitly substantive grounds. Most recently, in Baltimore Gas \& Electric Co. v. NRDC (Vermont Yankee IV), ${ }^{118}$ the Supreme Court again reversed the court of appeals.

Judge Bazelon's approach in Vermont Yankee III directly conflicts with the model of deference to quasi-legislative predictions. After scrutinizing the substance of the agency's decision, he concluded that the NRC's zero-risk finding was a "self-evident" error ${ }^{119}$ in light of considerable evidence of uncertainties in the long-term environmental consequences of the burial of nuclear wastes. Judge Bazelon characterized as equally unsatis-

109. See 44 Fed. Reg. 45,362, 45,369 (1979).

110. 547 F.2d 633 (D.C. Cir. 1976), rev'd sub nom. Vermont Yankee Nuclear Power Corp. v. NRDC, 435 U.S. 519 (1978) (Vermont Yankee II).

111. 547 F.2d at $643,645,653-54$.

112. Vermont Yankee Nuclear Power Corp. v. NRDC, 435 U.S. 519 (1978) (Vermont Yankee II). Justices Blackmun and Powell did not participate.

113. See id. at 539-41 (interpreting Vermont Yankee $I$ as turning on "perceived inadequacies of the procedures employed in the rulemaking" rather than on deficiencies in the AEC record).

114. See id. at 535-36 n.14.

115. NRC v. NRDC, 685 F.2d 459 (D.C. Cir. 1982) (Vermont Yankee III), rev'd sub nom. Baltimore Gas \& Elec. Co. v. NRDC, 103 S. Ct. 2246 (1983) (Vermont Yankee IV).

116. The Commission reiterated its zero-release finding following Vermont Yankee Nuclear Power Corp. v. NRDC, 435 U.S. 519 (1978) (Vermont Yankee II):

[F]or the limited purpose of the fuel cycle rule it is reasonable to base impacts on the assumption which the Commission believes the probabilities favor, i.e., that bedded-salt repository sites can be found which will provide effective isolation of radioactive waste from the biosphere.

44 Fed. Reg. 45,362, 45,369 (1979) (footnote omitted).

117. 685 F.2d at 494

118. 103 S. Ct. 2246 (1983).

119. 685 F.2d at 481 . 
factory the NRC's use of its zero-risk finding as a "decisionmaking device" that excluded consideration in licensing hearings of the uncertain environmental costs of permanent disposal of nuclear wastes. ${ }^{120}$ Because the agency admitted that although the environmental costs are small, fuel cycle considerations might well swing otherwise close decisions against licensing, ${ }^{121}$ Judge Bazelon concluded that forbidding consideration of fuel cycle effects in reaching reactor licensing decisions amounted to an explicit violation of the National Environmental Policy Act of 1969 (NEPA). ${ }^{\mathbf{1 2 2}}$

On the other hand, Judge Wilkey, dissenting, fully adopted the deferential model. ${ }^{123} \mathrm{He}$ argued that the NRG evaluated evidence on the frontiers of scientific knowledge, and that its prediction with respect to repository performance is precisely that type of "legislative policymaking" that deserves special deference. Judge Wilkey argued further that nuclear waste disposal does not pose major risks, and that the NRC's decision to remove the back end of the fuel cycle from consideration in individual reactor licensing proceedings therefore represented a reasonable exercise of discretion. ${ }^{124}$ In Vermont Yankee $I V,{ }^{125}$ a unanimous Supreme Court followed Judge Wilkey's reasoning and upheld the NRG's action. The Court characterized the Commission's approach as a reasonable one that balanced optimism over future repository performance in containing solid reactor wastes with cautious assumptions that all radioactive gases entrained in the wastes will escape before a repository is sealed. ${ }^{128}$ Explicitly affirming the model of deference to quasi-legislative agency findings, the Court reminded the lower court that the NRC's predictions lay "within its area of special expertise, at the frontiers of science," and that under such circumstances, "a reviewing court must generally be at its most deferential." 127

One does not come away from a reading of Vermont Yankee III and Vermont Yankee $I V$ with confidence in the usefulness of judicial deference to quasi-legislative predictions. ${ }^{128}$ Indeed, it is questionable whether the

120. Id. at $482-83$.

121. Id. at 484 .

122. Id.

123. 685 F.2d at 518 \& n.14 (Wilkey, J., dissenting).

124. Id. at 538,543 .

125. Baltimore Gas \& Elec. Co. v. NRDC, 103 S. Ct. 2246 (1983).

126. Id. at 2255-56.

127. Id. at 2256.

128. Nor does the performance of the parties encourage optimism about the prospects of using the traditional adversary process to resolve complex environmental disputes. As in earlier phases of this litigation, see Yellin, supra note 101, at 546-48, the parties were not helpful to the courts. The NRDC attacked the form of the Commission's finding, rather than its substance. See NRDG Response to Court's Order of Aug. 13, 1980, at 2, Vermont Yankee III, 685 F.2d 459 (D.C. Cir. 1982) (treatment of uncertainties in NRC proceedings unexceptionable, but exposition of uncertainties in final rule not sufficiently explicit). And the Commission confused the discussion by raising the possibility that fuel cycle effects may tilt the ultimate cost-benefit balance against an individual reactor. See 


\section{Environmental Decisionmaking}

Supreme Court in Vermont Yankee IV fully understood the implications of its application of the deference model for public acceptance of important environmental decisions. First, the Gourt did not recognize that the NRC's final rule did not directly address the public's concerns over nuclear waste. The Court declared itself impressed with the reasonableness of the Commission's "risk-averse" environmental assessment of the uranium fuel cycle. ${ }^{129}$ Yet the balance in the NRC's "balanced" view ignored the long-term risks of repository leakage that are central to the nuclear waste debate. Considering, as the Commission did, whether a small volume of radioactive gases will be released before a repository is sealed is not the same as considering the possibility, however distant, that highly toxic fission products and heavy elements will be released in large volume into the biosphere over the millennia during which such wastes remain hazardous for direct human exposure. ${ }^{130}$

Second, the Court failed to recognize that the Commission's zero-risk finding does not provide basic information critical for defensible risk analysis. Exploration and understanding of uncertainty are essential to good scientific research, to competent epidemiologic analysis, and to convincing econometric and cost-benefit studies of the type now often central to regulatory decisions. In these fields, depth of insight is achieved through an understanding of uncertainties and of their implications for further research. While an agency's risk estimates cannot always be judged using the standards of basic science, at a minimum an agency's treatment of uncertainty should be consistent with the best academic practice in the relevant fields. In Vermont Yankee, this consistency was lacking. The general theory of decisionmaking under uncertainty calls for decisions based on consideration of the details of social or individual preferences. In particular, if no special assumptions are made about the distribution of

44 Fed. Reg. 45,362, 45,363, 45,365 (1979). As Commissioner Gilinsky pointed out, id. at 45,374, this suggestion obscures the real implications of the fuel cycle debate. No universal yardstick can accurately measure the costs and benefits of fuel cycle activities and evaluate them in the context of other environmental and economic considerations routinely considered in every licensing action. A licensing board can decide whether the net benefits of reactor operation outweigh the putative costs associated with the fuel cycle. But given the crude decision instruments at hand, to declare that the risks of nuclear waste disposal tilt the cost-benefit balance against one reactor is also to say that no reactor should be built or operated. See id. at $45,374 \&$ n.1. It is naive to suppose that any NRC hearing board would reach such a decision. Vermont Yankee III and Vermont Yankee IV are therefore shadow versions of the debate about the legitimacy and long-term viability of the commercial nuclear power industry in which the courts have no institutional role.

129. Baltimore Elec. \& Gas Co. v. NRDC, 103 S. Ct. 2246, 2255 (1983).

130. More precisely, transuranic isotopes such as plutonium-239, a much discussed constituent of spent reactor fuel with a half-life of 24,000 years, are known to cause lung tumors in animals, after administration of inhaled doses as small as one microcurie. See W. BAIR, C. RICHMOND \& B. WACHHOLZ, A RADIOBIOLOGICAL ASSESSMENT OF THE SPATIAL DISTRIBUTION OF RADIATION DOSE FROM INHALED PLUTONIUM, at 14 (AEC Report WASH-1320, 1974) (table III-A). One microcurie of plutonium-239 amounts roughly to 25 millionths of a gram. 
decision outcomes or social preferences, there is no logically consistent decision rule that gives uncertainties zero weight. Yet uncertainties were given zero weight in computing the risk estimates the NRC presented in all three versions of the fuel cycle rule at issue in the Vermont Yankee litigation. ${ }^{131}$ In responding critically to the Commission's zero-risk finding, Judge Bazelon therefore restated a rationality requirement of the most fundamental and important sort. ${ }^{132}$

Nor does Vermont Yankee IV contribute to the balance among institutions essential to a healthy administrative system. The modern model of separated and divided powers calls for constructive cooperation among the legislature, agencies, and courts. ${ }^{133}$ Within the cooperative model, courts are called upon to set general standards for agency behavior. But Vermont

131. See 44 Fed. Reg. 45,362, 45,372-73 (1979) (codified at 10 C.F.R. $\$ \S 51.20(\mathrm{e}), 51.23(\mathrm{c})$ (1983)) (final table S-3); 42 Fed. Reg. 13,803, 13,806-07 (1977) (interim table S-3); 39 Fed. Reg. $14,188,14,191$ (1974) (original table S-3).

132. Vermont Yankee III is best read as suggesting that NEPA requires decisionmakers to incorporate in their environmental statements explicit rules for relatively weighting point estimates of risk and the associated uncertainties. In light of this interpretation, Vermont Yankee IV's rejection of Judge Bazelon's attack on the Commission's zero-risk rule is understandable. For although his arguments have merit as general propositions about the necessity for explicit treatment of environmental uncertainties, his approach to risk analysis is analytically unconvincing. "Risk" is not an observable entity. It is a concept that is defined by specifying a rule or reasoning process that combines observable components, such as the probability of a future event and its consequences, into a measure of risk. Yet Judge Bazelon directly equated uncertainties in the future environmental effects of nuclear waste disposal with "environmental costs," NRC v. NRDC, 685 F.2d 459, 483 (D.C. Cir. 1982) (Vermont Yankee III), rev'd sub nom. Baltimore Gas \& Elec. Co. v. NRDC, 103 S. Ct. 2246 (1983) (Vermont Yankee IV), without displaying the risk-building rule used to effect this transformation. Nor does Judge Bazelon make clear why he believes future fuel cycle effects must be entered on the cost side of the ledger. While it is true that reprocessing of spent fuel is now generally seen as economically infeasible and environmentally inadvisable, that position may change in the future with technological developments or shifts in energy policies.

Moreover, in another part of his argument, Judge Bazelon adopted a simple, widely used approach that equates risk with the product "probability" times "consequences," 685 F.2d at 478-79 \& n.100. Thus, he identified risk with the summary statistic "expected costs." But accepting, as Judge Bazelon did, NRDC v. NRG, 547 F.2d 633, 638-39 (D.C. Cir. 1976) (Vermont Yankee I), rev'd sub nom. Vermont Yankee Nuclear Power Corp. v. NRDC, 435 U.S. 519 (1978) (Vermont Yankee II), NRDC's position as to the catastrophic consequences of nuclear waste repository failures, the validity of the simple product form of risk is open to question. The catastrophes anticipated by the environmental plaintiffs in Vermont Yankee III include a destruction of community that is not captured analytically by the simple, risk-neutral product, "probability" times "consequences." Moreover, such catastrophes have implications for human community, sec K. ERIKSON, EVERYTHING IN ITS PATH: DESTRUCTION OF COMMUNITY IN THE BUFFALO CREEK FLOOD (1976), that transcend representation in terms of dollars spent and lives lost. See Kelman, Cost-Benefit Analysis: An Ethical Critique, REGULATION, Jan./Feb. 1981, at 33. The magnitude and interpersonal aspects of such an event suggest that the appropriate social preference function exhibits risk-aversion, leading to a non-linear dependence of risk upon putative consequences different from the simple linear product adopted by Judge Bazelon.

133. See Youngstown Sheet \& Tube Co. v. Sawyer, 343 U.S. 579, 635 (1952) (Jackson, J., concurring); United States v. Morgan, 307 U.S. 183, 191 (1939) (calling for agency-court cooperation); International Harvester Co. v. Ruckelshaus, 478 F.2d 615, 647 (D.C. Cir. 1973) (same in environmental context); Environmental Defense Fund v. Ruckelshaus, 439 F.2d 584, 597 (D.C. Cir. 1971) (same); G. CALABRESI, A COMMON LAW FOR THE AGE OF STATUTES 42, 50 (1982) (calling for revivified court-legislature balance); Cardozo, A Ministry of Justice, 35 HARV. L. REV. 113, 113-14 (1921) (proposing commission to mediate between agencies and courts). 


\section{Environmental Decisionmaking}

Yankee $I V$ s impeccable logic strikes a discordant note. For rather than taking the broad view essential for dispassionate oversight, the Court reads the NRC's decision in isolation from past AEC and NRC actions. It interprets the Commission's findings as a limited response to the anticipated performance of one disposal alternative-the placement of wastes in bedded salt. ${ }^{134}$ And ignoring the plain words of the Commission's justification for the final rule, ${ }^{135}$ it reads into the NRC's decision the conclusion that the uncertainties associated with waste repository performance "are not sufficient to affect the outcome" of individual reactor licensing actions. ${ }^{138}$ On this limited view, the Commission's decision is clearly supportable. Yet the Court's narrow reasoning demonstrates that the deference model is hollow. For Vermont Yankee $I V$ sets no standard of agency behavior, but instead disrupts the institutional balance by reaffirming the Court's past practice ${ }^{\mathbf{1 3 7}}$ of blocking judicial oversight of nuclear power regulation. ${ }^{138}$

In sum, the record suggests the Court has been insensitive to the implications of Vermont Yankee $I V$ for the legitimacy of the administrative process. This insensitivity is twofold. First, the Court has allowed its concern for the vitality of one important industry to override established procedural safeguards. Absent the forthright analysis of relevant uncertainties, numerical point estimates do not convey to decisionmakers and the public any sense of the seriousness of environmental hazards. ${ }^{139}$ The Court's approval of the NRC's zero-risk finding therefore conflicts with the settled rule that an administrative record must be sufficiently complete to permit effective review and efficient regulation, to be fair to regulatees, and to enable the education of the public and its officials. ${ }^{140}$

134. Baltimore Elec. \& Gas Co. v. NRDC, 103 S. Ct. 2246, 2255 (1983) (Vermont Yankee IV).

135. See supra note 128 (discussing rule).

136. Vermont Yankee IV, 103 S. Ct. at 2253.

137. See Vermont Yankee Nuclear Power Corp. v. NRDC, 435 U.S. 519 (1978) (Vermont Yankee II); Northern Indiana Pub. Serv. Co. v. Porter County Chapter of the Izaak Walton League, 423 U.S. 12 (1975) (per curiam); Power Reactor Dev. Co. v. International Union of Elec., Radio \& Mach. Workers, 367 U.S. 396 (1961).

138. See Yellin, supra note 101 , at 516 \& n.155. Nor has the Court consistently complied with the deference model. Vermont Yankee IV's solicitude for agency expertise in the face of scientific uncertainty was conspicuously absent from the Court's rejection of the benzene rule proposed by the Occupational Safety and Health Administration (OSHA). See Industrial Union Dep't v. American Petroleum Inst., 448 U.S. 607, 630-38, 652-58 (1980) (plurality opinion) (Benzene). The contrast is particularly acute in view of the NRC's obfuscation of the uncertainties in the risks of nuclear waste disposal and OSHA's forthright discussion of uncertainties in its estimates of the risk of cancer from low-level exposure to airborne benzene.

139. The final rule suggests the NRC agrees with this position. See 44 Fed. Reg. 45,362, 45,362 (1979) ("effuent release values, standing alone, do not meaningfully convey the environmental significance of uranium fuel cycle activities").

140. See, e.g., Weinberger v. Catholic Action of Hawaii/Peace Educ. Project, 454 U.S. 139, 143 (1981) (NEPA impact statement is intended to "inform the public that the agency has considered environmental concerns"); Massachusetts v. Watt, 716 F.2d 946, 948 (1st Cir. 1983) (holding unlaw- 
Second, the Court has failed to respond to a shift in the public's perception of the nature of environmental decisions. As biological discoveries provide us with a deeper understanding of health risks, society's view of the class of such risks important enough to deserve a response from government broadens. ${ }^{141}$ In consequence, environmental decisions that once would have been seen as purely social and technological have now taken on the attributes of decisions affecting the personal safety and integrity of citizens qua individual citizens. Clarity and fullness of explanation are central to the legitimacy of decisions affecting individual health and safety, ${ }^{142}$ and therefore to the legitimacy of the associated decision process. Once environmental decisions lose their pure social and technological character and take on the attributes of decisions directly affecting important individual interests, the same fullness of explanation becomes central to the legitimacy of the administrative state. ${ }^{143}$

\section{IV.}

Frankfurter's predictions have yet to be proved correct. The New Deal's administrative state responded in a limited way to specific political and economic problems. It did not sweep away the Blackstonian past, but

ful Interior Department's refusal to issue supplemental impact statement for offshore oil lease program, on grounds that decision documents before Secretary of Interior "did not describe the likely environmental harms well enough to ... [enable] an informed decision"); 42 U.S.C. § 7607(d)(3) (Supp. V 1978) (explanation required in EPA rulemaking regarding air quality); Comment, supra note 97 , at 202 (NEPA a device for publicly describing uncertainty).

141. See, e.g., Ruckelshaus, supra note 36, at 1027; RISK MGMT. REP., supra note 36, at 9-11 (noting increase in risk awareness).

142. See, e.g., Borel v. Fibreboard Paper Prods. Corp., 493 F.2d 1076 (5th Cir. 1973) (duty to warn industrial insulation workers of dangers of asbestos); Capron, Tort Liability in Genetic Counseling, 79 COLUM. L. REV. 619, 626 (1979) (importance of transmitting information on genetic risks); Note, Occupational Health Risks and the Worker's Right to Know, 90 YALE L.J. 1792 (1981) (proposing federal legislation requiring disclosure of health risks).

143. Sound economic reasoning also supports a requirement that technological decisions be fully explained. Efficient, fair operation of our mixed economy demands that private parties be free, once regulatory ground rules have been set, to act in their own best interests. They cannot do so effectively without knowing the details of the logic underlying administrative predictions. Moreover, we expect technological innovation in response to the need for better environmental controls. See, e.g., Society of the Plastics Indus., Inc. v. OSHA, 509 F.2d 1301, 1309 (2d Cir.) (OSHA regulations may require improvements in existing occupational hazard control technology), cert. denied, 421 U.S. 992 (1975). Yet in the presence of technological and scientific uncertainty, efficient incentives for innovation are not provided unless the logic relating societal means to goals is clearly laid out.

These arguments, in combination with those in the text, suggest a connection between an emergent right to know, see Emerson, Legal Foundations of the Right to Know, 1976 WASH. U. L.Q. 1; Brudney, Business Corporations and Stockholders' Rights Under the First Amendment, 91 YALE L. J. 235, 246-47 n.56 (1981), and the fair and efficient functioning of the modern administrative state.

The continuing reluctance of courts to impose full clarity requirements suggests the need for an explicit statutory requirement that administrators clearly set out assumptions, explain statistical or mathematical models, and identify gaps in technical information. For a legislative provision of this type, see the proposed Regulatory Reform Act, S. 1080, § 4(a), 97th Cong., 1st Sess. (1981) (proposed 5 U.S.C. $\S 622(\mathrm{c})(2)(\mathrm{D}))$. 


\section{Environmental Decisionmaking}

codified preexisting judicial and administrative relationships. ${ }^{144}$ It has not met ambiguous environmental goals, but rather articulated relatively unambiguous social and economic objectives. During the past forty years, the New Deal state has been severely tested. Ethyl, Reserve Mining, Vermont Yankee, and the other cases discussed above ${ }^{145}$ represent a sample of some eighty major technical and legal decisions ${ }^{146}$ that have run the course from legislative enactment to judicial review. These decisions were stimulated by discovery and innovation and are replete with mixtures of the technical and the political. Their histories make the need for institutional redesign clear. The traditional model of administrative law, ${ }^{147}$ freighted with private law conceptions ${ }^{148}$ and outmoded functional distinctions between agencies and courts, ${ }^{140}$ and limited by institutional competence ${ }^{\mathbf{1 5 0}}$ and finite judicial and administrative resources, simply cannot bear the weight we ask it to carry.

No viable reforms can shield generalist political institutions from scientific and technological complexity. Yet despite the interplay of the technical and political, with some notable exceptions ${ }^{161}$ judicial reluctance to address technical issues remains strong. ${ }^{162}$ This reluctance is manifest in

144. For a pre-APA comment emphasizing the consistency with past practices of the thenemergent APA review provisions, see Fuller, Administrative Law Investigation Comes of Age, 41 COLUM. L. REV. 589, 604-05 (1941).

145. See supra pp. 1315-16.

146. The work reported on in this Article is part of a larger ongoing study of environmental controversies, tentatively entitled "The Courts and Scientific Decisions." Analysis of 80 major cases reported reported between 1960 and 1983 reveals a gradual shift to more complex issues and toward deeper judicial involvement in technical matters. This observation motivates many of the arguments in this Article. Professor Rabin has summarized the results of a parallel analysis at this Symposium. See Rabin, Legitimacy, Discretion, and the Concept of Rights, 92 YALE L.J. 1174 (1983).

147. See Berle, The Expansion of American Administrative Law, 30 HARV. L. REV. 430 (1917); Stewart, supra note 9, at 1671-76.

148. See Chayes, The Role of the Judge in Public Law Litigation, 89 HARV. L. REV. 1281, 1282-83 (1976).

149. See Stewart, supra note 103, at 1811-20. But see Byse, supra note 103, at 1831-32 (demand for judicial imposition of procedural requirements on agency action reveals lack of trust in political process).

150. See Union of Concerned Scientists v. AEC, 499 F.2d 1069, 1089 (D.C. Cir. 1974) (erroneously asserting that failure of emergency core cooling system in commercial reactor is necessary condition for occurrence of large-scale accident); id. at 1089-90 (erroneously deducing from AEC staff report that reactor site selection criteria are based upon occurrence of largest feasible accident); Reserve Mining Co. v. EPA, 514 F.2d 492, 520 (8th Cir. 1975) (en banc) (noting "level of probability does not readily convert into a prediction of consequences"); supra note 132 . The lack of institutional competence in the judiciary to deal with complex decisions, see J. MASHAW, BUREAUCRATIC JUSTICE 193 (1983), was a New Deal theme. See, e.g., Cooper, supra note 3, at 596, 597, 599-600; Fuchs, supra note 3 , at 562 .

151. See supra pp. 1313-16.

152. See, e.g., Vermont Yankee Nuclear Power Corp. v. NRDC, 435 U.S. 519, 541-42 (1978) (Vermont Yankee $I I$ ) (reading lower court's mixed procedural and substantive holding as purely procedural); Greater N.Y. Hosp. Ass'n v, Mathews, 536 F.2d 494, 498 (2d Cir. 1976) (technical issues "simply not subject to judicial evaluation"); Wuillamey v. Werblin, 364 F. Supp. 237, 241 (D.N.J. 1973) (technical expertise needed to reach air quality finding renders agency decision unassailable in court). 
the model of deference to policymaking on the frontiers of science and technology. ${ }^{\mathbf{1 B s}}$ When technical aspects of public decisions are isolated from the mainstream of generalist institutional discussion, it is difficult to overcome the bureaucratic inertia that is universal to the modern administrative state ${ }^{154}$ and especially virulent in environmental regulation. ${ }^{155}$ In theory, court and legislature can break the inertial pattern by writing pointed legislation and by assuring that judicial oversight is sensitive to the full sweep of an agency's history. Yet in those instances in which technological issues are complex and agencies have grown sufficiently sophisticated to give the system of congressional mandate, administrative decision, and judicial review a real test, the results have not been encouraging. The Court's narrowly drawn argument in Vermont Yankee $I V^{158}$ provides only the most recent evidence that the presence of high technology enhances inertial effects by insulating administrative decisions from legislative and judicial oversight.

Study of the major environmental cases of the past two decades ${ }^{157}$ suggests that any viable institutional reforms should have five features: (1) For the legal, economic, and normative reasons already discussed, ${ }^{158}$ reforms must induce environmental decisionmakers to explain their predictions and reveal the value choices that inevitably underlie decisions made in the face of scientific uncertainty; ${ }^{159}$ (2) in order to avoid the taint of special interest, institutional innovation should be directed toward breaking the inertial pattern on a broad environmental front, from occupational health to nuclear power; (3) to build a reserve of experienced decisionmakers, an array of continuing, rather than ad hoc, institutions is required; (4) given the importance of institutional competence in confronting

153. See supra pp. 1320, 1323.

154. See, e.g., G. CALABRESI, supra note 133 , at 46, 53-54, 65, 72; Ackerman \& Hassler, Beyond the New Deal: Coal and the Clean Air Act, 89 YALE L.J. 1466, 1520 \& n.216 (1980).

155. These inertial effects account for the freezing of the technology for controlling sulfur emissions from conventional steam-electric power plants. See Ackerman \& Hassler, supra note 154, at $1466,1520-21$. Inertial effects are also apparent in the inflexible OSHA guidelines for dealing with the risks of exposure to putative carcinogens. See RISK MGMT. REP., supra note 36, at 64-65 (discussing 29 C.F.R. $\$ 1990.144($ e) (1983)). With bureaucratic inertia in mind, some courts have enjoined agency action pending preparation of an adequate NEPA statement. See, e.g., Massachusetts v. Watt, 716 F.2d 946, 951-53 (1st Cir. 1983) (offshore oil lease sale); NRDC v. NRG, 539 F.2d 824, 842 (2d Cir. 1976) (use of recycled plutonium in commercial nuclear reactors), vacated and remanded on other grounds sub nom. Allied-Gen. Nuclear Serv. v. NRC, 434 U.S. 1030 (1978); see also W. RODGERS, ENVIRONMENTAL LAW 767 (1977) (NEPA requires "consideration of environmental factors before project momentum is irresistible").

156. See supra pp. 1322-23.

157. See supra p. 1325.

158. See supra pp. 1323-24.

159. Cf. EPA Office of Public Affairs, News Release, July 12, 1983 (EPA Administrator offers to allow population of Tacoma, Wash., to participate in decision whether to close smelting operation emitting inorganic arsenic, under provisions of Clean Air Act). 
difficult substantive questions, and therefore in achieving legitimacy, ${ }^{160}$ technical communities should directly participate in decisionmaking; and (5) to be clearly perceived as legitimate and avoid interference with ordinary constitutional functions, the power of any new institution should flow from its personnel and the persuasiveness of its arguments, not from the direct delegation of authority.

With these requirements in mind, I have three suggestions. First, I propose the creation of a hybrid institution combining executive and legislative branch decisionmakers ${ }^{161}$ with experts from outside government. Under this proposal, the President would appoint a commission that would include the chairmen of the Council for Environmental Quality and the Council of Economic Advisors, the president of the National Academy of Sciences, the Attorney General, and selected members of Congress. The commission would also include rotating representatives from the biological, physical science, and engineering communities. The agency heads concerned would sit as ad hoc commission members. This commission would be charged with a scheduled review of environmental programs and would give special attention to areas in which scientific knowledge and technical data are incomplete. It would recommend large-scale policy choices and programs for future actions contingent on the results of ongoing research. ${ }^{162}$ It would formulate proposals for updating environmental statutes and transmit these proposals to the relevant congressional committees. The commission's enabling legislation would include procedures to assure floor consideration of its proposals during the year in which they are presented to Congress. ${ }^{163}$

This proposal does not shift the burden of inertia ${ }^{164}$ or force Congress' hand. Yet it is likely to provoke constructive action. The commissioners will be adept at addressing both political and technical problems. They will be insulated from the immediate pressures of policymaking and can

160. See Fiss, The Supreme Court, 1978 Term-Foreword: The Forms of Justice, 93 HaRV. L. REV. 1, 38 (1979).

161. But $c f$. G. CALABRESI, supra note 133, at 63 (arguing that hybrid executive-legislative commission for updating statutes would either exercise unchecked executive power or take on responsibilities properly belonging to courts).

162. Cf. RISK MGMT. REP., supra note 36, at 81 (calling for risk assessment guidelines that can accommodate evolving scientific knowledge).

163. The updating and congressional reporting features of this proposal are modeled in part on sunset legislation proposed in 1979 by Senator Kennedy. See S. BREYER, supra note 27, at 366-67 (discussing S. 1291, 96th Cong., 1st Sess. (1979)). The suggestion for a hybrid commission is motivated by the success of the Warren Commission, REPORT OF THE PRESIDENT'S COMM'N ON THE ASSASSINATION OF PRESIDENT KENNEDY (1964); the Kerner Commission, REPORT OF THE NAT'L ADVISORY COMAM'N ON CIVIL DISORDERS (1968); the Social Security Commission, Report of the Nat'l Comm'n on Social Security Reform, 46 SOC. SECURITY BULL. 3 (1983); and the Scowcroft Commission, REPORT OF THE PRESIDENT'S COMM'N ON STRATEGIC FORCES (1983) (MX missile system).

164. See G. CALABRESI, supra note 133 , at 60,65 . 
avoid the pitfalls of long-term decisionmaking driven solely by crisis. ${ }^{165}$

Second, I propose creating surrogates for democratic representation within the regulatory agencies. The Separatists' conclusions may be incorrect, ${ }^{168}$ but they do us a service by pointing out that in the absence of practical distinctions between the technical and the political, nothing prevents administrators from using their discretion gradually to draw political decisions under the cloak of expertise, effectively precluding public participation in environmental decisions. ${ }^{167} \mathrm{~A}$ surrogate for democratic decisionmaking can be constructed by taking advantage of the contrast in styles and intellectual approaches among the technical disciplines. ${ }^{188}$ One attractive alternative is to use two different planning groups within each agency, one based intellectually in economics, the other in biology. ${ }^{169}$ Experience suggests that the economic planners will attempt to minimize the quantifiable costs of proposed regulations ${ }^{170}$ through the use of price incentives. ${ }^{171}$ In contrast, the biological planners will tend to emphasize extrapolation to man from the results of in vitro toxicity experiments, animal models, or known effects of chemicals and radiation in simple or-

165. See, e.g., J. KRIER \& E. URSIN, POLLUTION AND POLICY 263-74, 299-300 (1977) (discussing role of pollution crises in generating widespread-though often adventitious and evanescent-public support for environmental controls).

166. See supra p. 1307.

167. See supra pp. 1317-18.

168. The analytic power of interdisciplinary professional debate is revealed, for example, in the quality of the debates between earth scientists and physicists over the applicability of easily manipulable models in dealing with the intricacies of long-term ground transport of nuclear wastes, see U.S. ENVIRONMENTAL PROTECTION AGENCY, STATE OF GEOLOGIC KNOWLEDge REGARDING POTENTIAL TRANSPORT OF HIGH-LEVEL RADIOACTIVE WASTE FROM DEEP CONTINENTAL DEPOSITORIES 29-30 (1978) (report 520/4-78-004) (report of ad hoc panel of earth scientists), and in the debate between soil and atmospheric scientists over the relative role and significance of atmospheric and soil chemistry in mediating the effects of acid rain, see Krug \& Frink, Acid Rain on Acid Soil: A New Perspective, 221 SCIENCE 520 (1983).

The energy of the clash between biological and physical science research philosophies could have profitably been called upon at different stages in the nuclear safety debate by including biologists in discussions otherwise reserved for physicists and engineers. In response to continuing debate about the reliability of the methodology and arguments used by the NRC in assessing the risks of nuclear power, the Commssion created an ad hoc review group. See AD HOC RISK ASSESSMENT REVIEW GROUP, REPORT TO THE U.S. NUCLEAR REGULATORY COMMISSION (1978) (NRC Consultant's Report NUREG/CR-0400). Although much of the required analysis concerned the health effects of exposure to ionizing radiation, no biologists participated. Thus, the NRC did not take advantage of the advice of researchers with a commitment to understanding diverse living systems through laboratory analysis, rather than achieving the physical scientist's ultimate goal of simplicity and depth of theoretical understanding. Cf. Remarks of Howard Temin, in THE JOYS OF RESEARCH 79, 80-81 (W. Shropshire ed. 1981) (discussing Gamow, Information Transfer in the Living Cell, SCI. AM., Oct. 1955, at 70, as example of irrelevance of pure theory to progress in molecular biology).

169. Each agency and area of regulation poses its own distinctive problems that deserve an individualized institutional response. See Gellhorn \& Robinson, Perspectives on Administrative Law, 75 COLUM. L. REV. 771, 787-88 (1975); Rabin, Administrative Law in Transition: A Discipline in Search of an Organizing Principle, 72 NW. U.L. REV. 120 (1977).

170. See A. KNeEse \& C. Schultze, POllution, PRices ANd Public Policy 12, 28,29 (1975).

171. See, e.g., id. at 105-07; J. KRIER \& E. URSIN, supra note 165, at 35-36, 301-04. 
ganisms, ${ }^{172}$ and exhibit a countervailing preference for health-based standards and direct regulation. Under this proposal, the two planning groups would report independently on identical policy questions formulated by the agency head. Agencies could then regulate in light of two alternative sets of findings that would be part of the public record. The quality of ultimate decisions, in light of comments from the technical and social science communities and the results of judicial review, should make the burdens and benefits of this experiment clear.

This suggestion moves the administrative process away from the centralized models for regulatory reform that have frequently been proposed. ${ }^{173}$ The rationale for centralized regulation is increased efficiency, stability, and predictability of decisions. One can argue that competition breeds instability; that a public clash of views detracts from the legitimacy of decisions; ${ }^{174}$ that duplication creates conflict that inevitably leads to inferior decisions shaped by advocacy, bargaining, and compromise, rather than by substance; and therefore that the resulting administrative process would be unable to respond to discovery and innovation. I am persuaded, however, that innovations of this kind can increase flexibility and speed decisionmaking by encouraging an earlier, more open debate over the substance of technological decisions within the agencies, rather than in the White House, Congress, and the courts. The costs of internalizing dis-

172. See, e.g., McCann \& Ames, The Salmonella/Microsome Mutagenicity Test: Predictive Value for Animal Carcinogenicity, in ORIGINS OF HUMAN CANCER: BOOK C, HUMAN RISK ASSESS. MENT 1431, 1446-47 (T. Hiatt, J. Watson \& J. Winsten eds. 1977) (arguing on basis of mutagenicity experiments on Salmonella bacteria and other evidence that industrial chemicals cause somatic mutations in cellular DNA, and that Salmonella/microsome test provides precise and rapid in vitro method for identifying environmental mutagens and minimizing human exposure); Popper, Selikoff, Maltoni, Squire \& Thomas, Comparison of Neoplastic Hepatic Lesions in Man and Experimental Animals, in id. at 1359 (comparing etiology of liver tumors in man and rodents, and concluding observed similarities support extrapolation from animals to man). Of course, attitudes toward environmental regulation within biology and economics differ, and personnel choices must insure that an agency has a roughly balanced pair of planning views.

The proposal does not rely upon modification of the existing advisory system. E.g., 29 U.S.C. § 656 (1976) (National Advisory Committee on Occupational Safety and Health); 42 U.S.C. $\S 2039$ (1976) (NRC Advisory Committee on Reactor Safeguards); 21 C.F.R. $\$ 14.100$ (1983) (standing FDA advisory committees). When constituted without regard to the institutional affiliations of prospective members, advisory committees are often useful in bringing a deeper perspective to an agency's technical analysis. But they can also lead to nonconstructive posturing and confrontation. Compare T. Greenwood, Knowledge and Discretion in Regulation 173-74 (1983) (unpublished manuscript on file with Yale Law Journal) (narrowly focused EPA Science Advisory Board deliberations have improved agency risk assessments, helped identify and sometimes resolve controversies, correct technical errors) with id. at 174 (statutory instruction to constitute OSHA advisory committees with balance of employer and employee viewpoints provided little more than forum for contention and only rarely helped agency in risk assessment or engineering analyses of regulatory options). The emphasis here is upon institutional reforms that integrate dissonant professional views within an agency.

173. E.g., COMM'N ON LAW AND THE ECONOMY, supra note 27, at 79-88; Cutler, supra note 27, at 553; Cutler \& Johnson, supra note 27, at 1414-17. See generally S. BREYER, supra note 27, at 359 60 (describing proposals to give President veto power over administrative action).

174. Cf. Ruckelshaus, supra note 36 , at 1028 (public interest not served when federal agencies openly disagree on hazards of same substance). 
agreements within agencies may well be outweighed by the benefits of a multi-disciplinary approach that encourages more open choices among diverse values, and revitalizes representative government. ${ }^{175}$

Finally, a review of the last two environmental decades suggests that our nineteenth-century system of judicial oversight needs help if it is to deal competently with the problems of twentieth-century technological society ${ }^{176}$ A science advisory body for the federal judiciary could provide that help. Elsewhere, I have suggested one model, in which an advisory group of standing masters is associated with the federal appellate courts. ${ }^{177}$ This proposal seeks to encourage a critical, continuing dialogue between the scientific and engineering communities and the courts. Judges could call upon the masters in complex cases presenting issues on the frontiers of research and innovation. I conceive of a two-stage proceeding. The first stage would focus, consistent with present master's practices, ${ }^{178}$ on technical questions proposed by the court. In the second stage, the masters would examine the appellate record in the context of the whole case, giving thought to open scientific questions, discussing these questions informally with appropriate members of the technical community, and reporting to the court on the implications of their studies for future litigation. ${ }^{179}$

175. The value of overlapping institutional responsibilities and of intra-organizational competition are also themes of the literature on organizations. See Landau, Redundancy, Rationality and the Problem of Duplication and Overlap, 29 PUB. ADMIN. REV. 346 (1969); Sapolsky, Solution to the "Health Crisis," 3 POL'Y ANALYSIS 115, 118, 121 (1977); Sapolsky, Organizational Competition and Monopoly, 17 PUB. POL'Y 355, 376 (1968).

176. See cases cited supra note 150. That the courts would benefit from scientific advice is not a new idea. See Parke-Davis \& Co. v. H.K. Mulford Co., 189 F. 95, 115 (S.D.N.Y. 1911) (L. Hand, J.) (need for expert chemist to examine evidence in adrenalin patents litigation).

177. See Yellin, supra note 101, at 555-59; cf. Texas v. EPA, 499 F.2d 289, 308 n.31 (5th Cir. 1974) (scale of court's effort needed to understand model for regional air pollution suggests that appointment of special master would have been desirable), cert. denied, 427 U.S. 905 (1976). Other writers have made similar proposals for the use of masters and magistrates, see Note, The Environmental Court Proposal: Requiem, Analysis, and Counterproposal, 123 U. PA. L. REv. 676, 692-96 (1975), and for special science advisors to the judiciary, see Kaufman, Judicial Reform in the Next Century, 29 STAN. L. REV. 1, 23-24 (1976).

178. See FED. R. CIV. P. 53(b) (permitting reference to master in jury cases when issues are complex, and in nonjury cases only when required by "exceptional condition").

179. But see Wald, Making "Informed" Decisions on the District of Columbia Circuit, 50 GEO. WASH. L. REV. 135, 152 (1981) (rejecting masters' proposal on ground it derogates adversary system). Judge Wald's article and this one begin from common ground. She points out that lawyers often stress doctrinal rather than real-life arguments, and that sometimes a client's interests will not be promoted by addressing and uncovering the full ramifications of a case. Id. at 147 . Therefore the adversary process structured and directed by the parties often cannot help judges to reach a full understanding of an agency record.

Judge Wald suggests allowing courts to reconvene the parties after oral argument, with experts included, for an informal interrogatory. This would occur after the writer of an opinion had been chosen and the court had identified ambiguities or inconsistencies in a long and complex record. She suggests that courts follow Judge Leventhal's lead in Alabama Power Co. v. Costle, 606 F.2d 1068, 1093 (D.C. Cir. 1979), and allow the parties to comment on a "proposed opinion."

In making this proposal, Judge Wald suggests that courts can function in much the same fashion as 


\section{Environmental Decisionmaking}

Some may prefer that the courts sharply limit their role in environmental controversies, ${ }^{180}$ effectively withdrawing from technological decisionmaking, but that is not a realistic prospect. Cases that inextricably mix the legal and technical will continue to test the judicial system. Generalist judges will continue to define government's responsibilities in adjusting to technological change and to strike a balance between the use of new technology and the preservation of otherwise immutable values. ${ }^{181}$ Moreover, the demise of the legislative veto ${ }^{\mathbf{1 8 2}}$ can only intensify the pressures on Congress to revert to practices of an earlier $\mathrm{era}^{183}$ and give detailed environmental instructions it could otherwise have left unspecified, ${ }^{184}$ ultimately drawing the courts deeper into reviewing the substance of environmental decisions.

We should have no qualms about the modest changes in the scope of the judicial role that these proposals entail. There is no evidence that judges, given the opportunity, can or will take control over environmental policy. Indeed, their reluctance to do so is manifest. ${ }^{185}$ Nor is it likely that judges will allow expert advisors to exercise judicial power.

The introduction of informal procedures into the appellate process will

the masters' committee suggested in this Article. Her suggestion is a good one. It should be tried in a variety of technical cases. It is an open question, however, whether major improvements of decisions are likely without investments in time beyond what is practical for appellate judges. But see Wald, supra, at 153-54 (stressing likelihood of net saving of judicial time).

180. See Breyer, Vermont Yankee and the Courts' Role in the Nuclear Energy Controversy, 91 HARV. L. REV. 1833, 1845 (1978).

181. See City of Akron v. Akron Center for Reproductive Health, Inc., 103 S. Ct. 2481, 2496 (1983) (striking down municipal statute requiring all second-trimester abortions to be performed in hospital, in view of excellent outpatient care now available). Even more difficult issues are emerging. See Fetal Research, New Field Offers Promise Amid Problems, N.Y. Times, July 5, 1983, at C1, col. 5 (use of tissues from aborted fetuses for treatment of disease).

182. INS v. Chadha, 103 S. Ct. 2764 (1983).

183. See, e.g., Act of July 7, 1838, ch. 191, § 7, 5 Stat. 304, 305 (master of steamboat required to open boiler safety valve whenever vessel docks); id. $\S 9,5$ Stat. at 306 (iron rods and chain to be used in steamboat navigation, rather than wheel or tiller ropes).

184. Ten of 56 selected current statutory provisions authorizing a legislative veto, see INS v. Chadha, 103 S. Ct. 2764, 2811-16 (1983) (White, J., dissenting), and therefore presumptively invalidated by Chadha, deal with important environmental concerns. See 43 U.S.C.A. $\$ \$ 1713(c), 1714$ (West Supp. 1983) (sale of public lands may be disapproved by concurrent resolution); Pub. L. No. 96-539, § 4, 94 Stat. 3194, 3195 (1980) (to be codified at 7 U.S.C. $§ 136 w$ ) (EPA regulations under FIFRA); Pub. L. No. 96-510, § 305, 94 Stat. 2767, 2809 (1980) (to be codified at 42 U.S.C. § 9655) (regulations concerning release of hazardous substances); 10 U.S.C. $\$ 7422(c)(2)(C)(1976)$ (production period for petroleum reserves); 50 U.S.C. app. $\$ \S 2406(\mathrm{~d})(2)(\mathrm{B}), 2406(\mathrm{~g})(3)$ (Supp. V 1981) (domestic crude oil production); Pub. L. No. 96-464, § 12, 94 Stat. 2060, 2067 (1980) (to be codified at 16 U.S.C. \$ 1463a) (regulations governing coastal zone management); 16 U.S.C. § 1432 (1982) (designation of marine sanctuaries); Pub. L. No. 96-294, $\S \S 126,128,129,94$ Stat. 611, 644-49, 65054 (1980) (to be codified at 42 U.S.C. $\$ \S 8722,8724,8725$ ) (comprehensive plan for synthetic fuels development); 42 U.S.C. $\$ 5919$ (m) (Supp. V 1981) (international agreements concerning storage of spent nuclear fuel); 42 U.S.C. $\$ 6421$ (c) (1976) (presidential orders with respect to energy conservation and pricing).

185. See Ethyl Corp. v. EPA, 541 F.2d 1, 34-37 (D.C. Gir.) (en banc), cert. denied, 426 U.S. 941 (1976); Union of Concerned Scientists v. AEC, 499 F.2d 1069, 1094 (D.C. Cir. 1974); International Harvester Co. v. Ruckelshaus, 478 F.2d 615, 650 (D.C. Cir. 1973) (Bazelon, C.J., concurring). 
restrict the rights and protections guaranteed by the formal adversary system. Yet making environmental decisionmaking less formal is not necessarily undesirable. That the traditional party-controlled process is used for environmental decisionmaking, despite the restrictions imposed by justiciability, is less evidence of concern for individual rights than recognition of the seriousness of the issues. In effect, we have used the adversary system to make environmental decisions as an experiment in ways to make wiser long-term choices. The adversary system is not, however, an essential source of legitimacy for technological decisions. On the contrary, in technical controversies, scathing superficial questioning by counsel intent on winning a case increases skepticism about the usefulness and legitimacy of the formal adversary process and discourages expert participation. ${ }^{188}$ Moreover, while party control of legal controversies induces lawyers' support for the judicial system, legitimacy does not flow from a process in which important environmental decisions are shaped by lawyers whose training, predilections, and skills are not attuned to the issues of central importance. Nor is legitimacy enhanced when simplistic analyses of complex environmental problems ${ }^{187}$ or encyclopedic treatment of peripheral issues ${ }^{\mathbf{1 8 8}}$ are encouraged. When sophisticated technical language and art play central roles in the substance of decision, when more is needed than simple judgments of whether policy analysts have considered all important factors, ${ }^{189}$ or when decisions turn on deductions from complex models, ${ }^{190}$ substance-independent adversary techniques at best give the imprimatur, not the reality, of independent oversight. ${ }^{191}$ The essential task is to enable a form of judicial review that can maintain a balance among law-enforcing, law-interpreting, and law-making institutions. In an era of discovery and innovation, achieving such a balance demands the thorough integration of scientific judgment into the judicial process.

Resolution of the antinomy ${ }^{\mathbf{1 9 2}}$ between independent judicial review and

186. See Friendly, "Some Kind of Hearing," 123 U. PA. L. REV. 1267, 1285 n.92 (1975) (expert participation discouraged by prospect of hectoring cross-examination).

187. See McGarity, supra note 25 , at 750,777 ; Wald, supra note 179 , at 147; Yellin, supra note 101 , at 505-08, 529-31, 546-48.

188. See Society of the Plastics Indus., Inc. v. OSHA, 509 F.2d 1301, 1304 (2d Cir.) (criticizing "blunderbuss" approach to environmental litigation), cert. denied, 421 U.S. 992 (1975).

189. See Strycker's Bay Neighborhood Council, Inc. v. Karlen, 444 U.S. 223, 227-28 (1980) (per curiam); id. at 231 (Marshall, J., dissenting); Yellin, supra note 101, at 545 \& n.337.

190. See, e.g., Sierra Club v. Costle, 657 F.2d 298, 332-36 (D.C. Cir. 1981) (econometric model of public utility behavior in response to coal price differentials and to variable EPA standards for use of coal with varying sulfur content); Cleveland Elec. Illuminating Co. v. EPA, 572 F.2d 1150, 1160 (6th Cir.) (model of atmospheric dispersion of sulfur emissions from coal-fired power plant), cert. denied, 439 U.S. 910 (1978); Texas v. EPA, 499 F.2d 289, 294-96 (5th Cir. 1974) (reduction model for hydrocarbon emissions), cert. denied, 427 U.S. 905 (1976).

191. See Ethyl Corp. v. EPA, 541 F.2d 1, 69 (D.C. Cir.) (en banc) (Leventhal, J., concurring), cert. denied, 426 U.S. 941 (1976).

192. Cf. NLRB v. Stow Mfg. Co., 217 F.2d 900, 905 (2d Cir. 1954) (L. Hand, J.) (recognition 
reliance on the best scientific judgment is not imminent. It will require nurturing generalist decisionmakers' understanding of new developments in science and technology. The goal is to assure that decisionmakers can respond flexibly and constructively to swiftly changing regulatory problems. ${ }^{193}$ While institutional reforms may resolve the crises of legitimacy and competence that now confront the administrative state, ${ }^{194}$ there are more important concerns. Our survival as a functioning nation through the end of this century depends on our reasonableness in making technological decisions. We serve ourselves by making a commitment throughout our educational system and government to exposing the real complexities of these decisions.

of administrative expertise "involves an abdication by the "lay' courts"; no general principle solves the "antinomy of their retaining any review whatever"), cert. denied, 348 U.S. 964 (1955).

193. See RISK MGMT. REP., supra note 36 , at $78-79$, 165.

194. See J. FREEDMAN, CRISIS AND LEGITIMACY 10-12 (1978). 